\title{
Chemical Profile of Launaea nudicaulis Ethanolic Extract and Its Antidiabetic Effect in Streptozotocin-Induced Rats
}

\author{
Samah A. El-Newary ${ }^{1}$, Sherif M. Afifi ${ }^{2}$, Mohamed S. Aly ${ }^{3}{ }^{\circledR}$, Rania F. Ahmed $\left.{ }^{4}{ }^{(}\right)$, Abd El-Nasser G. El Gendy ${ }^{1}{ }^{(D}$, \\ Ahmed M. Abd-ElGawad ${ }^{5, *}\left(\mathbb{D}\right.$, Mohamed A. Farag ${ }^{6,7}$, Abdelbaset M. Elgamal ${ }^{8, *}$ and Abdelsamed I. Elshamy ${ }^{4}(\mathbb{D}$ \\ 1 Medicinal and Aromatic Plants Research Department, National Research Centre, 33 El Bohouth St., Dokki, \\ Giza 12622, Egypt; samahelnewary@yahoo.com (S.A.E.-N.); aggundy_5@yahoo.com (A.E.-N.G.E.G.) \\ 2 Pharmacognosy Department, Faculty of Pharmacy, University of Sadat City, Sadat City 32897, Egypt; \\ shshsh38@hotmail.com \\ 3 Department of Animal Reproduction and Artificial Insemination, National Research Centre, 33 El Bohouth St., \\ Dokki, Giza 12622, Egypt; mohamedaly_nrc@yahoo.com \\ 4 Chemistry of Natural Compounds Department, National Research Centre, 33 El Bohouth St., Dokki, \\ Giza 12622, Egypt; rfawzi@hotmail.com (R.F.A.); elshamynrc@yahoo.com (A.I.E.) \\ 5 Department of Botany, Faculty of Science, Mansoura University, Mansoura 35516, Egypt \\ 6 Pharmacognosy Department, College of Pharmacy, Cairo University, Kasr el Aini St., Cairo P.B. 11562, Egypt; \\ mfarag73@yahoo.com \\ 7 Chemistry Department, School of Sciences \& Engineering, The American University in Cairo, \\ New Cairo 11835, Egypt \\ 8 Department of Chemistry of Microbial and Natural Products, 33 El-Bohouth St., Dokki, Giza 12622, Egypt \\ check for \\ updates \\ * Correspondence: aibrahim2@ksu.edu.sa (A.M.A.-E.); algamalgene@yahoo.com (A.M.E.); \\ Tel.: +966-562680864 (A.M.A.-E.); +20-1001558689 (A.M.E.)
}

Citation: El-Newary, S.A.; Afifi, S.M.; Aly, M.S.; Ahmed, R.F.; El Gendy, A.E.-N.G.; Abd-ElGawad, A.M.; Farag, M.A.; Elgamal, A.M.; Elshamy, A.I. Chemical Profile of Launaea nudicaulis Ethanolic Extract and Its Antidiabetic Effect in Streptozotocin-Induced Rats. Molecules 2021, 26, 1000. https:// doi.org/10.3390/molecules26041000

Academic Editors: Hosam O. Elansary and Agnieszka Szopa

Received: 13 January 2021

Accepted: 7 February 2021

Published: 13 February 2021

Publisher's Note: MDPI stays neutral with regard to jurisdictional claims in published maps and institutional affiliations.

Copyright: (c) 2021 by the authors. Licensee MDPI, Basel, Switzerland. This article is an open access article distributed under the terms and conditions of the Creative Commons Attribution (CC BY) license (https:/ / creativecommons.org/licenses/by/ $4.0 /)$.
Abstract: Launaea nudicaulis is used in folk medicine worldwide to treat several diseases. The present study aimed to assess the antidiabetic activity of L. nudicaulis ethanolic extract and its effect on diabetic complications in streptozotocin-induced hyperglycemic rats. The extract was orally administrated at 250 and $500 \mathrm{mg} / \mathrm{kg} /$ day for 5 -weeks and compared to glibenclamide as a reference drug at a dose of $5 \mathrm{mg} / \mathrm{kg} /$ day. Administration of the extract exhibited a potential hypoglycemic effect manifested by a significant depletion of serum blood glucose concurrent with a significant elevation in serum insulin secretion. After 5-weeks, extract at 250 and $500 \mathrm{mg} / \mathrm{kg} /$ day decreased blood glucose levels by about 53.8 and $68.1 \%$, respectively, compared to the initial values $(p \leq 0.05)$. The extract at the two dosages prevented weight loss of rats from the 2 nd week till the end of the experiment, compared to diabetic control rats. The extract further exhibited marked improvement in diabetic complications including liver, kidney and testis performance, oxidative stress, and relative weight of vital organs, with respect to diabetic control. Histopathological examinations confirmed the previous biochemical analysis, where the extract showed a protective effect on the pancreas, liver, kidney, and testis that degenerated in diabetic control rats. To characterize extract composition, UPLC-ESI-qTOF-MS identified 85 chromatographic peaks belonging to flavonoids, phenolics, acyl glycerols, nitrogenous compounds, and fatty acids, with four novel phenolics reported. The potential anti-diabetic effect warrants its inclusion in further studies and or isolation of the main bioactive agent(s).

Keywords: Launaea nudicaulis; antihyperglycemic; liver and kidney functions; histopathological studies; metabolites profiling; LCMS

\section{Introduction}

Diabetes mellitus (DM) is a long-term condition and one of the degenerative diseases affecting the life-quality of individuals and their families and societies. This disease is one of the most chronic widespread community diseases worldwide. In 2019, the global diabetes prevalence was estimated at $9.30 \%$ (463 million people), which could reach $10.20 \%$ (578 million people) by 2030 and 10.90\% (700 million people) by 2045 [1,2]. Worldwide, 
Egypt, with 8.9 million people, is considered one of the top five countries in the Middle East and North Africa for diabetes prevalence, according to Thomas et al. [2]. Diabetes mellitus is one of the main reasons for glucose autoxidation, protein glycation, and polyol metabolism activation. These syndromes cause the acceleration of reactive oxygen species generation that increases the levels of oxidized forms of DNA, proteins, and lipids in several body tissues and therefore increases oxidative stress. All the syndromes of DM and its complications can be basically correlated with the oxidative stress [3]. There is a positive relation between STZ-induced hyperglycemia (type-1) and oxidative stress resulting in diabetes complications, including alterations in tissue, lipid peroxidation, protein inhibition, and glycation [4]. Also, there is a relation between insulin resistance and oxidative stress, causing a disruption in glucose and lipid metabolism concurrent with inhibition of the antioxidant enzyme system. Consequently, many antioxidant chemicals exhibit hypoglycemic effects that enable them to be used as diabetes medications. Several chemical hypoglycemic drugs are used, including insulin, sulfonylureas, metformin, Na+-glucose exchanger inhibitors, meglitinides, GLP-1 agonists, dipeptidyl peptidase- 4 inhibitors, insulin analogs and $\alpha$-glucosidase inhibitors. These drugs have, nevertheless, side effects warranting the search for new hypoglycemic natural compounds with less side effects [5]. Reproductive dysfunction and male testicular damage are consequences of DM in both humans and animals. DM decreases testicular weight, sperm count, motility, and plasma testosterone levels, along with alterations of the spermatogenesis process [6], induces cellular apoptosis, and triggers male infertility [7]. Nevertheless, the testicular histopathological alterations has never been deeply studied and these examinations could possibly aid in judging the efficacy and safety of newly emerged antidiabetic agents.

Medicinal plants are commonly used in traditional medicine worldwide due to their distribution, safety, efficacy, and relatively low costs [8]. Launaea nudicaulis (L.) Hooker fil. is commonly known as Al-Hewa in the Arabic region. Its leaves are used in folk medicine for the treatment of children's fever, skin itches, eczema, swelling, bilious fever, ulcers, and cuts $[9,10]$. Numerous pharmaceutical uses were documented for the different extracts of L. nudicaulis i.e., antioxidant [10], insecticidal, cytotoxic, antifungal [11] and antimicrobial activity [9]. Chemical classes reported in L. nudicaulis include essential oils [9,10], flavonoids, phenolics, alkaloids [12], sesqui-, di-, and triterpenoid/steroids in addition to sphingolipids [13]. We have previously reported the chemical characterization, antioxidant and phytotoxic activities of essential oils of three Launaea plants including $L$. nudicaulis [10]. Due to the history of the genus in addition to the potent biological activities of L. nudicaulis especially, antioxidant potentiality, existing evidence suggested that it has potential antidiabetic activity [14-17].

Continuing our goal in exploring the biological potential of Egyptian plants in relation to their chemical profiles [18,19], the present work aimed to (i) determine the antidiabetic effect of L. nudicaulis ethanolic extract in streptozotocin (STZ)-induced diabetic (type-1) rats, (ii) study of the potentiality of the extract to act against complications of DM and iii) construct the chemical profile of the extract using UPLC-ESI-qTOF-MS.

\section{Results and Discussion}

\subsection{Acute Toxicity}

Oral administration of a single dose of different concentrations of L. nudicaulis EtOH extract (1-3 g/ $\mathrm{kg}$ body weight) to albino mice groups did not induce any mortality during the first $48 \mathrm{~h}$. After the first $48 \mathrm{~h}$, no mortality was observed during the followed 14 days with these concentrations, compared to negative control. The mortality started with concentration at $4 \mathrm{~g} / \mathrm{kg} /$ day till $6 \mathrm{~g} / \mathrm{kg} /$ day. The concentration that killed $50 \%$ of animals during the first $48 \mathrm{~h}$ was estimated at $5 \mathrm{~g} / \mathrm{kg} /$ day (Table S1).

\subsection{Effect on Blood Glucose Levels}

Data presented in Table 1 reveals the effect of L. nudicaulis ethanol extract on blood glucose levels of STZ- induced diabetic rats and post five weeks, compared to the diabetic 
control. The extract showed a significant effect on blood glucose level and significantly minimized it during the experimental period, compared to the diabetic control. An increase of the extract doses from $250 \mathrm{mg} / \mathrm{kg}$ to $500 \mathrm{mg} / \mathrm{kg}$ significantly increased its hypoglycemic effect from 3rd week until the end of the experiment.

Table 1. Glucose level (mg/dL) of STZ- induced diabetic rats treated with L. nudicaulis ethanolic extract during 5-weeks.

\begin{tabular}{|c|c|c|c|c|c|c|}
\hline \multirow{2}{*}{ Treatments } & \multicolumn{6}{|c|}{ Blood Glucose Level (mg/dL) } \\
\hline & Start Time & 1st Week & 2nd Week & 3rd Week & 4th Week & 5th Week \\
\hline Negative control & $124.0 \pm 6.12^{\circ}$ & $\begin{array}{c}126.6 \pm 7.77^{\circ} \\
0.2 \% \text { * }\end{array}$ & $\begin{array}{c}127.6 \pm 8.32^{\circ} \\
2.9 \%\end{array}$ & $\begin{array}{c}123.8 \pm 7.92^{\circ} \\
-0.2 \%\end{array}$ & $\begin{array}{c}125.8 \pm 7.46^{\circ} \\
1.5 \%\end{array}$ & $\begin{array}{c}126.2 \pm 5.63^{\circ} \\
1.8 \%\end{array}$ \\
\hline Diabetic control & $411.9 \pm 17.53^{d}$ & $\begin{array}{c}434.4 \pm 15.19^{c} \\
5.5 \%\end{array}$ & $\begin{array}{c}467.2 \pm 15.56^{b} \\
13.42 \%\end{array}$ & $\begin{array}{c}485.9 \pm 17.17^{\mathrm{a}} \\
18.0 \%\end{array}$ & $\begin{array}{c}486.3 \pm 20.07^{\mathrm{a}} \\
18.0 \%\end{array}$ & $\begin{array}{c}486.00 \pm 25.22 \mathrm{a} \\
18.0 \%\end{array}$ \\
\hline $\begin{array}{l}\text { L. nudicaulis (250 } \\
\mathrm{mg} / \mathrm{kg} / \text { day) }\end{array}$ & $408.5 \pm 8.86^{\mathrm{d}}$ & $\begin{array}{c}302.5 \pm 17.23 \mathrm{~h}^{\mathrm{h}} \\
-26.0 \%\end{array}$ & $\begin{array}{c}254.1 \pm 11.48^{\mathrm{k}} \\
-37.8 \%\end{array}$ & $\begin{array}{c}225.9 \pm 11.47^{1} \\
-44.7 \%\end{array}$ & $\begin{array}{c}217.8 \pm 10.28^{1} \\
-46.70 \%\end{array}$ & $\begin{array}{c}188.4 \pm 7.71 \mathrm{~m} \\
-53.9 \%\end{array}$ \\
\hline $\begin{array}{l}\text { L. nudicaulis (500 } \\
\mathrm{mg} / \mathrm{kg} / \text { day) }\end{array}$ & $410.0 \pm 9.13^{d}$ & $\begin{array}{c}364.4 \pm 11.97^{\mathrm{f}} \\
-11.1 \%\end{array}$ & $\begin{array}{c}263.6 \pm 14.67^{j} \\
-35.7 \%\end{array}$ & $\begin{array}{c}194.6 \pm 9.41 \mathrm{~m} \\
-52.5 \%\end{array}$ & $\begin{array}{c}161.1 \pm 4.85^{\mathrm{n}} \\
-60.7 \%\end{array}$ & $\begin{array}{c}130.9 \pm 5.61^{\circ} \\
-68.1 \%\end{array}$ \\
\hline $\begin{array}{l}\text { Glibenclamide } \\
\text { (5 mg/kg/day) }\end{array}$ & $408.7 \pm 5.71^{\mathrm{d}}$ & $\begin{array}{c}380.7 \pm 17.38^{\mathrm{e}} \\
-6.9 \%\end{array}$ & $\begin{array}{c}354.7 \pm 10.72 \mathrm{~g} \\
-13.2 \%\end{array}$ & $\begin{array}{c}289.9 \pm 14.16^{\mathrm{i}} \\
-29.1 \%\end{array}$ & $\begin{array}{c}244.7 \pm 9.76^{\mathrm{k}} \\
\quad-40.1 \%\end{array}$ & $\begin{array}{c}198.4 \pm 7.87 \mathrm{~m} \\
-51.5 \%\end{array}$ \\
\hline
\end{tabular}

Data presented as mean \pm SE $(n=10)$. Data were analyzed using ANOVA two-way followed with post hoc for multiple comparisons. The means followed by the same letter are not significantly different from each other at $5 \%$ probability level (Duncan s multiple range test). * means the change $(\%)=(($ glucose level at the start time-glucose level of the 1 st week $) /$ glucose level at the start time $) \times 100$.

Additionally, the time recorded a significant effect on blood glucose levels, compared to the level at the start-time, except the negative control, where time had no significant effect. Blood glucose of diabetic control showed significant elevation compared to the value at the start time. Blood glucose of L. nudicaulis extract-treated and standard control groups significantly were decreased along the experimental period to reach the lowest level at the 5th week. Administration of L. nudicaulis $\mathrm{EtOH}$ extract at two doses for one week significantly decreased blood glucose levels. Continuing the extract administration for another four weeks showed a continuous reduction in blood glucose levels to reach the highest effect at the 5th week, compared to diabetic control. L. nudicaulis extract at $500 \mathrm{mg} / \mathrm{kg}$ recorded the minimum blood glucose level at 5th week $(130.86 \pm 5.61 \mathrm{mg} / \mathrm{dL})$, compared to diabetic control $(486.00 \pm 25.22 \mathrm{mg} / \mathrm{kg}$ ) at the same time. Blood glucose level of $500 \mathrm{mg} / \mathrm{kg}$ treated group at the 5 th week $(130.86 \pm 5.61 \mathrm{mg} / \mathrm{dL})$ was close to that of the negative control $(126.20 \pm 5.63 \mathrm{mg} / \mathrm{dL})$ at the same time.

\subsection{Effect on Serum Insulin Levels}

Diabetic control recorded a significant reduction in serum insulin levels of rats $(81.04 \pm 5.20 \mathrm{mIU} / \mathrm{mL})$ after 5-weeks, compared to $197.90 \pm 7.61 \mathrm{mIU} / \mathrm{mL}$ in the negative control $(p \leq 0.05)$. EtOH extract of L. nudicaulis at the two doses $(250$ and $500 \mathrm{mg} / \mathrm{kg}$ ) significantly maximized serum insulin level of treated groups to $207.78 \pm 4.05$ and $314.09 \pm 5.30 \mathrm{mIU} / \mathrm{mL}$, respectively, with 156.39 and $287.57 \%$ increase than that of diabetic control; $81.04 \pm 5.20 \mathrm{mIU} / \mathrm{Ml}(p \leq 0.05)$ (Figure 1). The extract attained serum insulin close to that recorded in the negative control or slightly higher. 


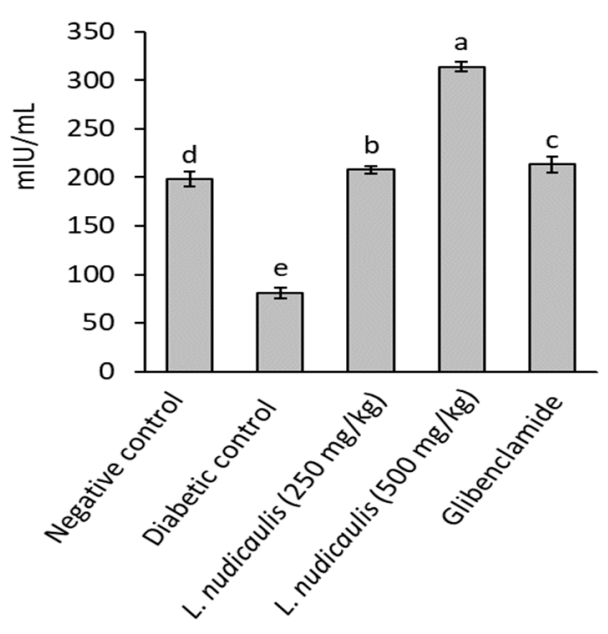

Figure 1. Insulin concentration of STZ- induced diabetic rats treated with L. nudicaulis ethanolic extract during 5-weeks. Data are presented as the means \pm SE $(n=10)$. Data analyzed by ANOVA one-way. Value with the different superscript letters means significance at a probability level of 0.05 .

\subsection{Effect on Rats Weekly Body Weight}

Administration of STZ in rats led to a significant decrease in body weight over the time of the experiment $(p \leq 0.05)$ till the end, compared to the rats in the negative control group (Table 2). Plant extract-treated groups and glibenclamide drug showed, in contrast, a restoration in rats' weight till the end of the experiment. Weekly body weight of the treated groups normally increased from 3-week and continued in significant increase till the 5-week, in comparison with the diabetic control. The effect of L. nudicaulis on body weight was similar to the effect of a standard drug.

Table 2. Body weight (g) of STZ- induced diabetic rats treated with L. nudicaulis ethanolic extract for 5-weeks.

\begin{tabular}{|c|c|c|c|c|c|c|}
\hline Time & Start Time & 1-Week & 2-Weeek & 3-Week & 4-Week & 5-Week \\
\hline $\begin{array}{l}\text { Negative } \\
\text { control }\end{array}$ & $167.0 \pm 4.97 \mathrm{~g}, \mathrm{~h}$ & $\begin{array}{l}180.4 \pm 7.12^{\mathrm{f}} \\
+13.4^{*}\end{array}$ & $\begin{array}{c}190.0 \pm 5.30^{\mathrm{d}} \\
+9.6\end{array}$ & $\begin{array}{c}197.8 \pm 3.71^{\mathrm{c}} \\
+7.8\end{array}$ & $\begin{array}{c}212.4 \pm 5.15^{b} \\
+14.6\end{array}$ & $\begin{array}{c}227.0 \pm 3.92^{\mathrm{a}} \\
+14.6\end{array}$ \\
\hline $\begin{array}{l}\text { Diabetic } \\
\text { Control }\end{array}$ & $166.1 \pm 4.36^{\mathrm{g}, \mathrm{h}}$ & $\begin{array}{c}153.8 \pm 3.69 \mathrm{j}, \mathrm{k} \\
-12.3\end{array}$ & $\begin{array}{c}138.8 \pm 5.80 \mathrm{~m}, \mathrm{n} \\
-15.0\end{array}$ & $\begin{array}{c}133.4 \pm 3.61^{\mathrm{n}} \\
-5.4\end{array}$ & $\begin{array}{c}123.4 \pm 1.80^{\circ} \\
-10.0\end{array}$ & $\begin{array}{c}107.5 \pm 1.67 \mathrm{p} \\
-15.5\end{array}$ \\
\hline $\begin{array}{l}\text { L. nudicaulis } \\
250 \mathrm{mg} / \mathrm{kg}\end{array}$ & $150.0 \pm 13.30^{k, 1}$ & $\begin{array}{c}134.1 \pm 1.51^{\mathrm{n}} \\
-15.9\end{array}$ & $\begin{array}{c}147.0 \pm 4.97^{1} \\
+12.9\end{array}$ & $\begin{array}{c}161.2 \pm 9.66^{\mathrm{h}, \mathrm{i}} \\
+14.2\end{array}$ & $\begin{array}{c}167.0 \pm 7.42 \mathrm{~g} \\
+5.8\end{array}$ & $\begin{array}{c}196.2 \pm 11.22^{c} \\
+29.2\end{array}$ \\
\hline $\begin{array}{l}\text { L. nudicaulis } \\
500 \mathrm{mg} / \mathrm{kg}\end{array}$ & $161.0 \pm 11.81 \mathrm{~g}, \mathrm{~h}, \mathrm{i}$ & $\begin{array}{c}150.1 \pm 8.28^{k, 1} \\
-10.9\end{array}$ & $\begin{array}{c}156.9 \pm 6.20^{i, j} \\
+6.8\end{array}$ & $\begin{aligned} 165.7 & \pm 6.37 \mathrm{~g}, \mathrm{~h} \\
& +8.9\end{aligned}$ & $\begin{array}{c}183.9 \pm 7.45^{\mathrm{e}, \mathrm{f}} \\
+18.2\end{array}$ & $\begin{array}{c}210.2 \pm 9.12^{b} \\
+26.4\end{array}$ \\
\hline $\begin{array}{l}\text { gilbenclamide } \\
5 \mathrm{mg} / \mathrm{kg} / \text { day }\end{array}$ & $162.0 \pm 7.47 \mathrm{~g}, \mathrm{~h}, \mathrm{i}$ & $\begin{array}{c}140.0 \pm 6.73^{\mathrm{m}} \\
-22.0\end{array}$ & $\begin{array}{c}153.0 \pm 10.21^{\mathrm{j}, \mathrm{k}} \\
+13.0\end{array}$ & $\begin{array}{c}167.0 \pm 3.08 \mathrm{~g}, \mathrm{~h} \\
+14.0\end{array}$ & $\begin{array}{c}181.3 \pm 6.39^{\mathrm{f}} \\
+14.3\end{array}$ & $\begin{array}{c}189.8 \pm 3.40^{\mathrm{d}, \mathrm{e}} \\
+8.5\end{array}$ \\
\hline
\end{tabular}

Data are presented as the means \pm SE $(n=10)$. Data of wight analyzed by ANOVA two-way. Value with different letters has significant variation at $p<0.05 .{ }^{*}$ indicates weekly body weight gain = body weight of week-body weight of the previous week.

\subsection{Effect on Lipid Profile}

The diabetic control rats were characterized by disrupted lipid profiles manifested by a significant elevation in TC, TG, and VLDL-C, and LDL-C levels (Table 3), concurrently with a significant reduction in HDL-C level, in comparison to the same parameters in the negative control $(p \leq 0.05)$. Lipid profile biomarkers of diabetic rats were enhanced when rats administrated the extract either at a low or high dose level, compared to the diabetic control. TC, TG, VLDL-C, and LDL-C levels showed significant reductions nearly to the normal levels than that recorded in the negative control. 
Table 3. Lipid profile of STZ- induced diabetic rats treated with L. nudicaulis ethanolic extract for 5-weeks.

\begin{tabular}{|c|c|c|c|c|c|c|}
\hline Groups & $\begin{array}{c}\text { TC } \\
(\mathrm{mg} / \mathrm{dL})\end{array}$ & $\begin{array}{l}\text { HDL-C } \\
(\mathrm{mg} / \mathrm{dL})\end{array}$ & $\begin{array}{c}\text { TG } \\
(\mathrm{mg} / \mathrm{dL})\end{array}$ & $\begin{array}{l}\text { VLDL-C } \\
\text { (mg/dL) }\end{array}$ & $\begin{array}{c}\text { LDL-C } \\
(\mathrm{mg} / \mathrm{dL})\end{array}$ & $\begin{array}{c}\text { Risk Ratio } \\
\%\end{array}$ \\
\hline $\begin{array}{c}\text { Negative } \\
\text { control }\end{array}$ & $82.30 \pm 7.33^{c}$ & $49.10 \pm 2.91^{\mathrm{a}}$ & $142.87 \pm 2.85^{c}$ & $28.57 \pm 0.57^{c}$ & $5.09 \pm 0.94^{\mathrm{d}}$ & $0.11 \pm 0.01^{d}$ \\
\hline Diabetic control & $194.86 \pm 10.65^{\mathrm{a}}$ & $34.45 \pm 1.40^{\mathrm{c}}$ & $232.90 \pm 8.43^{a}$ & $46.58 \pm 1.69^{a}$ & $113.83 \pm 6.75^{\mathrm{a}}$ & $3.33 \pm 0.25^{\mathrm{a}}$ \\
\hline $\begin{array}{l}\text { L. nudicaulis } 250 \\
\mathrm{mg} / \mathrm{kg} / \text { day }\end{array}$ & $88.29 \pm 6.88^{b}$ & $44.96 \pm 1.61^{b}$ & $148.26 \pm 7.72^{b}$ & $29.65 \pm 1.54^{b}$ & $13.68 \pm 0.94^{c}$ & $0.31 \pm 0.03^{\mathrm{c}}$ \\
\hline $\begin{array}{l}\text { L. nudicaulis } 500 \\
\mathrm{mg} / \mathrm{kg} / \text { day }\end{array}$ & $92.28 \pm 5.25^{b}$ & $44.20 \pm 2.46^{\mathrm{b}}$ & $136.08 \pm 7.35^{\mathrm{d}}$ & $27.22 \pm 1.47^{\mathrm{d}}$ & $20.88 \pm 1.43^{b}$ & $0.47 \pm 0.04^{b}$ \\
\hline $\begin{array}{l}\text { Glibenclamide } \\
5 \mathrm{mg} / \mathrm{kg} / \text { day }\end{array}$ & $94.54 \pm 5.00^{b}$ & $46.05 \pm 3.12^{b}$ & $150.18 \pm 4.81^{\mathrm{b}}$ & $30.05 \pm 0.96^{b}$ & $18.60 \pm 1.90^{b}$ & $0.41 \pm 0.03^{b}$ \\
\hline
\end{tabular}

Values represent means $\pm \mathrm{SE}(n=10)$. Means with different letters within the same column are significantly different $p \leq 0.05$.

Also, the HDL-C level was significantly raised and back to its normal level. The risk ratio was also improved as a response to the improvement of lipid profile in the $L$. nudicaulis EtOH extract-treated groups. The effect of the extract on the lipid profile was similar to that of glibenclamide drug in TC, TG and VLDL-C, and LDL-C levels.

\subsection{Effect on Liver and Kidney Functions}

Liver performance of the diabetic control rats was disrupted as evidenced by a significant reduction in total protein production and its fractions; albumin and globulin, concurrent with a significant elevation on AST, ALT, and ALP activities, compared to the corresponding values in the negative control $(p \leq 0.05)$. L. nudicaulis EtOH extract returned liver performance of treated-rats towards normalization, where total protein, albumin, and globulin production were significantly raised, concurrently with a significant reduction on AST, ALT, and ALP activities in comparison with the corresponding values on the diabetic control (Table 4). No significant difference was recorded between the effect of a low and high dose of the extract on the liver functions of treated rats, except in albumin and globulin. Compared to the drug glibenclamide, the extract recorded the highest ameliorative effect on liver function

Table 4. Liver functions of STZ-induced diabetic rats treated with L. nudicaulis ethanolic extract during 5-weeks.

\begin{tabular}{ccccccc}
\hline Groups & $\begin{array}{c}\text { Total Protein } \\
\text { g/dL }\end{array}$ & Albumin g/dL & Globulin g/dL & $\begin{array}{c}\text { AST } \\
\text { U/L }\end{array}$ & $\begin{array}{c}\text { ALT } \\
\text { U/L }\end{array}$ & $\begin{array}{c}\text { ALP } \\
\text { U/L }\end{array}$ \\
\hline $\begin{array}{c}\text { Negative } \\
\text { control }\end{array}$ & $7.39 \pm 0.44^{\mathrm{a}}$ & $4.08 \pm 0.34^{\mathrm{c}}$ & $3.31 \pm 0.64^{\mathrm{a}}$ & $57.35 \pm 4.47^{\mathrm{c}}$ & $31.08 \pm 3.77^{\mathrm{c}}$ & $64.84 \pm 36.80^{\mathrm{c}}$ \\
$\begin{array}{c}\text { Diabetic control } \\
\text { L. } \begin{array}{c}\text { nudicaulis } 250 \\
\text { mg/kg/day }\end{array}\end{array}$ & $7.81 \pm 0.26^{\mathrm{b}}$ & $2.91 \pm 0.13^{\mathrm{d}}$ & $1.89 \pm 0.32^{\mathrm{c}}$ & $119.56 \pm 8.87^{\mathrm{a}}$ & $84.41 \pm 6.16^{\mathrm{a}}$ & $95.84 \pm 3.40^{\mathrm{a}}$ \\
$\begin{array}{c}\text { L. nudicaulis } 500 \\
\text { mg/kg/day }\end{array}$ & $7.22 \pm 0.55^{\mathrm{a}}$ & $5.21 \pm 0.23^{\mathrm{a}}$ & $1.94 \pm 0.66^{\mathrm{c}}$ & $86.23 \pm 3.89^{\mathrm{b}}$ & $42.60 \pm 3.40^{\mathrm{b}}$ & $75.20 \pm 0.79^{\mathrm{b}}$ \\
$\begin{array}{c}\text { Glibenclamide } \\
5 \mathrm{mg} / \mathrm{kg} / \text { day }\end{array}$ & $7.19 \pm 0.55^{\mathrm{a}}$ & $4.81 \pm 0.28^{\mathrm{b}}$ & $2.39 \pm 0.34^{\mathrm{b}, \mathrm{c}}$ & $91.99 \pm 5.20^{\mathrm{b}}$ & $44.48 \pm 2.45^{\mathrm{b}}$ & $71.35 \pm 0.76^{\mathrm{b}}$ \\
\hline
\end{tabular}

AST: aspartate aminotransferase; ALT: alanine aminotransferase; ALP: Alkaline phosphatase; Values represent means \pm SE $(n=10)$. Means with different letters within the same column are significantly different $p \leq 0.05$.

Diabetes induction disrupted renal performance, causing a significant $(p \leq 0.05)$ elevation in creatinine, uric acid, and urea concentrations of the diabetic control rats in comparison with the corresponding values in the negative control (Table 5). L. nudicaulis $\mathrm{EtOH}$ extract restored renal functions of diabetic rats towards normalization by forcefeeding low or high dose, compared to that of the diabetic control. The extract of $L$. nudicaulis caused amelioration on uric acid and urea equal or higher than that caused by glibenclamide. 
Table 5. Renal functions of STZ- induced hyperglycemic rats treated with L. nudicaulis ethanolic extract.

\begin{tabular}{cccc}
\hline Groups & $\begin{array}{c}\text { Creatinine } \\
\mathbf{m g} / \mathbf{d L}\end{array}$ & $\begin{array}{c}\text { Uric Acid } \\
\mathbf{m g} / \mathbf{d L}\end{array}$ & $\begin{array}{c}\text { Urea } \\
\mathbf{~ m g} / \mathbf{d L}\end{array}$ \\
\hline Negative control & $1.21 \pm 0.02^{\mathrm{d}}$ & $4.11 \pm 0.08^{\mathrm{d}}$ & $4.32 \pm 0.05^{\mathrm{e}}$ \\
Diabetic control & $2.42 \pm 0.08^{\mathrm{a}}$ & $11.91 \pm 0.30^{\mathrm{a}}$ & $8.29 \pm 0.09^{\mathrm{a}}$ \\
L. nudicaulis $50 \mathrm{mg} / \mathrm{kg} /$ day & $1.71 \pm 0.08^{\mathrm{b}}$ & $7.10 \pm 0.20^{\mathrm{b}}$ & $5.42 \pm 0.12^{\mathrm{c}}$ \\
L. nudicaulis $500 \mathrm{mg} / \mathrm{kg} /$ day & $1.64 \pm 0.05^{\mathrm{b}}$ & $5.10 \pm 0.14^{\mathrm{c}}$ & $4.91 \pm 0.10^{\mathrm{d}}$ \\
Glibenclamide $5 \mathrm{mg} / \mathrm{kg} /$ day & $1.41 \pm 0.04^{\mathrm{c}}$ & $6.89 \pm 0.14^{\mathrm{b}}$ & $6.55 \pm 0.17^{\mathrm{b}}$ \\
\hline
\end{tabular}

Values represent means \pm SE $(n=10)$. Means with different letters within the same column are significantly different $p \leq 0.05$.

\subsection{Effect On Relative Weight of Vital Organs}

Data in Table 6 shows the effect of L. nudicaulis EtOH extract on the relative weight of vital organs of STZ-induced diabetic rats, in comparison to diabetic control. All vital organs were enlarged as a response to diabetes induction, compared to the negative control, except the pancreas, where it showed atrophy and decreased by $29.73 \%$ than that of the negative control. On the other hand, L. nudicaulis extract administration for 5-weeks returned all vital organs toward normalization. The relative weight of the pancreas of L. nudicaulisgroups was significantly elevated to be within the normal range, compared to the diabetic control. Compared to glibenclamide drug, relative weight of vital organs of L. nudicaulisgroups were nearer to that of the negative control.

Table 6. Relative weight of organs of STZ- induced diabetic rats treated with L. nudicaulis ethanolic extract.

\begin{tabular}{|c|c|c|c|c|c|c|c|c|}
\hline Groups & Liver & Kidney & Spleen & Brain & Pancreas & Heart & Lung & Testes \\
\hline Negative control & $4.14 \pm 0.26^{\mathrm{c}, \mathrm{d}}$ & $0.84 \pm 0.05^{\mathrm{c}}$ & $0.67 \pm 0.07^{\mathrm{b}}$ & $0.80 \pm 0.10^{\mathrm{b}, \mathrm{c}}$ & $0.37 \pm 0.07^{\mathrm{b}}$ & $0.37 \pm 0.04^{b}$ & $0.74 \pm 0.10^{b, c}$ & $1.31 \pm 0.15^{c}$ \\
\hline Diabetic control & $6.23 \pm 0.16^{\mathrm{a}}$ & $1.13 \pm 0.04^{\mathrm{a}}$ & $0.75 \pm 0.05^{\mathrm{a}}$ & $1.09 \pm 0.08^{\mathrm{a}}$ & $0.26 \pm 0.08^{c}$ & $0.45 \pm 0.09^{a}$ & $1.00 \pm 0.22^{\mathrm{a}}$ & $1.95 \pm 0.28^{a}$ \\
\hline $\begin{array}{c}\text { L. nudicaulis } 250 \\
\mathrm{mg} / \mathrm{kg} / \text { day }\end{array}$ & $4.84 \pm 0.14^{b}$ & $0.97 \pm 0.19^{b}$ & $0.57 \pm 0.13^{c}$ & $0.8 \pm 0.29^{b, c}$ & $0.47 \pm 0.04^{\mathrm{a}}$ & $0.38 \pm 0.06^{b}$ & $0.85 \pm 0.23^{b}$ & $1.60 \pm 0.04^{b}$ \\
\hline $\begin{array}{l}\text { L. nudicaulis } 500 \\
\mathrm{mg} / \mathrm{kg} / \text { day }\end{array}$ & $4.29 \pm 0.37^{c}$ & $0.79 \pm 0.05^{\mathrm{c}}$ & $0.52 \pm 0.11^{c}$ & $0.76 \pm 0.02^{\mathrm{c}}$ & $0.36 \pm 0.06^{b}$ & $0.36 \pm 0.04^{b}$ & $0.70 \pm 0.03^{c}$ & $1.29 \pm 0.03^{c}$ \\
\hline $\begin{array}{c}\text { Glibenclamide } 5 \\
\mathrm{mg} / \mathrm{kg} / \text { day }\end{array}$ & $4.06 \pm 0.26^{\mathrm{d}}$ & $1.01 \pm 0.10^{b}$ & $0.57 \pm 0.09^{c}$ & $0.93 \pm 0.13^{b}$ & $0.37 \pm 0.04^{b}$ & $0.45 \pm 0.08^{a}$ & $0.78 \pm 0.04^{b, c}$ & $1.47 \pm 0.24^{b}$ \\
\hline
\end{tabular}

Values represent means $\pm \mathrm{SE}(n=10)$. Means with different letters within the same column are significantly different $p \leq 0.05$.

\subsection{Effect on Serum Antioxidant and Oxidative Stress Biomarkers}

Diabetes induction is associated with remarkable oxidative stress conditions that result in a significant decrease in antioxidant enzyme activities and glutathione concentration, concurrent with a significant elevation in malondialdehyde (MDA, a lipid peroxidation biomarker) levels. Data shown in Table 7 pointed to diabetic control rats were characterized by significant depletion in GSH concentration accompanied with significant decrease in activities of antioxidant enzymes; CAT, GR, GST and GPx, as well as significant increase in MDA content with respect to the negative control values $(p<0.05)$. In comparison with diabetic control results, extract of $L$. nudicaulis showed remarkable antioxidant activity that represented as a significant elevation on GSH level and significant activation on antioxidant enzymes; CAT, GR, GST, and GPx of diabetic rat's as well as significant depletion on MDA content $(p<0.05)$. The therapeutic effect of $L$. nudicaulis extract on antioxidant enzymes and GSH concentration and MDA content was close to that of the drug glibenclamide. 
Table 7. Serum malondialdehyde and antioxidant biomarkers of STZ- induced hyperglycemic rats treated with L. nudicaulis ethanolic extract.

\begin{tabular}{|c|c|c|c|c|c|c|}
\hline Groups & $\begin{array}{c}\text { MDA } \\
\mathrm{nmol} / \mathrm{mL}\end{array}$ & $\begin{array}{l}\text { CAT } \\
(\mathrm{U} / \mathrm{L})\end{array}$ & $\begin{array}{c}\text { GSH } \\
(\mathrm{mg} / \mathrm{dL})\end{array}$ & $\begin{array}{l}\mathrm{GR}(\mu \mathrm{mol} / \mathrm{mg} \\
\text { protein } / \mathrm{min})\end{array}$ & $\begin{array}{c}\mathrm{GST}(\mu \mathrm{mol} / \mathrm{mg} \\
\text { protein } / \mathrm{min})\end{array}$ & $\begin{array}{c}\mathrm{GPx}(\mu \mathrm{mol} / \mathrm{mg} \\
\text { protein } / \mathrm{min})\end{array}$ \\
\hline $\begin{array}{c}\text { Negative } \\
\text { control }\end{array}$ & $3.54 \pm 0.31^{\mathrm{e}}$ & $118.82 \pm 7.77^{\mathrm{a}}$ & $4.70 \pm 0.24^{c}$ & $5.80 \pm 0.29^{c}$ & $3.91 \pm 0.20^{d}$ & $2.40 \pm 0.12^{b}$ \\
\hline Diabetic control & $10.414 \pm 0.23^{a}$ & $86.96 \pm 9.26^{\mathrm{d}}$ & $1.76 \pm 0.20^{\mathrm{d}}$ & $1.86 \pm 0.21^{\mathrm{d}}$ & $1.32 \pm 0.15^{\mathrm{e}}$ & $0.80 \pm 0.09^{c}$ \\
\hline $\begin{array}{c}\text { L. nudicaulis } 250 \\
\mathrm{mg} / \mathrm{kg} / \text { day }\end{array}$ & $6.43 \pm 0.33^{b}$ & $108.89 \pm 4.49^{b, c}$ & $4.682 \pm 0.09^{c}$ & $5.92 \pm 0.12^{c}$ & $4.11 \pm 0.08^{c}$ & $2.26 \pm 0.06^{b}$ \\
\hline $\begin{array}{l}\text { L. nudicaulis } 500 \\
\mathrm{mg} / \mathrm{kg} / \text { day }\end{array}$ & $4.46 \pm 0.31^{\mathrm{d}}$ & $113.46 \pm 5.47^{\mathrm{a}, \mathrm{b}}$ & $5.22 \pm 0.14^{\mathrm{a}}$ & $6.89 \pm 0.18^{a}$ & $4.34 \pm 0.20^{b}$ & $2.78 \pm 0.07^{\mathrm{a}}$ \\
\hline $\begin{array}{l}\text { Glibenclamide } \\
5 \mathrm{mg} / \mathrm{kg} / \text { day }\end{array}$ & $5.02 \pm 0.36^{c}$ & $103.20 \pm 6.04^{c}$ & $4.94 \pm 0.29 b$ & $6.37 \pm 0.37^{b}$ & $5.40 \pm 0.31^{\mathrm{a}}$ & $2.67 \pm 0.14^{a}$ \\
\hline
\end{tabular}

Values represent means $\pm \mathrm{SE}(n=10)$. Means with different letters within the same column are significantly different $p \leq 0.05$. MDA; malondialdehyde; GSH; glutathione-L-reduced, GR; glutathione reductase, GST; glutathione-S-transferase, GPx; glutathione peroxidase, and CAT; catalase.

\subsection{Histological Examination of Pancreas, Liver, Kidney, and Testis}

\subsubsection{Pancreas}

The negative control rats showed the normal histology of the pancreas without any architectural changes (Figure 2a). In contrast, diabetic control rats showed severe disorganization of the structure of the endocrine and exocrine cells, shrunken islets with a drastic reduction in the number, necrosis in Langerhans islets; acinar cells were swollen and showed small vacuoles (Figure $2 \mathrm{~b}$ ). Some pancreatic islet cells were degenerated and vacuolated, other cells showed cellular apoptosis (Figure 2c). The glibenclamide group showed normal pancreatic structures with exocrine acini surrounding the islets of Langerhans (Figure 2d). L. nudicaulis $250 \mathrm{mg}$ group showed moderate necrotic changes of the pancreas associated with a mild reduction in the size and number of the islets of Langerhans (Figure 2e). The effect of L. nudicaulis $(500 \mathrm{mg} / \mathrm{kg})$ on STZ treated rats group showed a remarkable recovery as compared to the STZ treated rats, with a mild degree of necrosis in islets of Langerhans (Figure 2f).

\subsubsection{Kidney}

H\&E staining of kidney indicated that the glomerular structure was normal in all negative control rats (Figure 3a). Diabetic control rats showed atrophy of glomerular tuft, degeneration of renal tubules, and increase in the Bowman' space area associated with severe hemorrhage and congestion of renal blood vessels (Figure 3b,c). L. nudicaulis $250 \mathrm{mg}$ group showed moderate necrotic changes with mild congestion of renal blood vessels (Figure 3e). Improvement in the histopathological picture was most noticed in the L. nudicaulis $500 \mathrm{mg}$ group, with marked recovery and amelioration of the pathological picture associated with the restoration of normal renal architecture (Figure 3f) close to that of glibenclamide group (Figure 3d). 


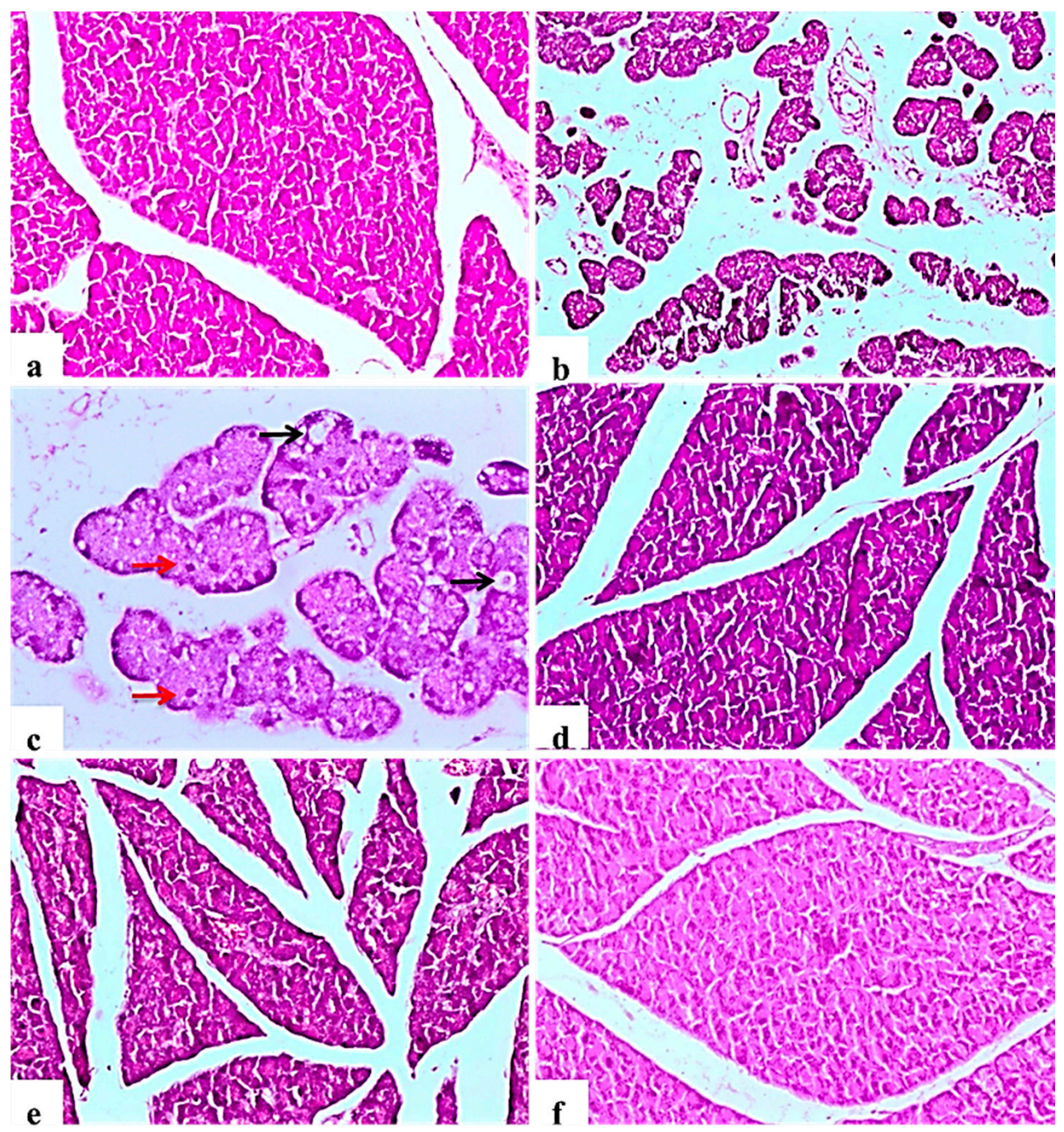

Figure 2. Light photomicrographs of pancreatic tissue $(H \& E \times 100)$. (a): control rat showing normal architecture of the pancreas, acinar cells and arranged into small lobules, pancreatic lobules separated by intact intralobular and interlobular connective tissue septa. (b): Subgroup I (diabetic control) showing disorganization of the structure of the endocrine and exocrine cells, shrunken islets with a drastic decrease in the number, necrosis in Langerhans islets, acinar cells were swollen and vacuolated. (c): Some islet cells have degenerated and vacuolated (Black arrows), cellular apoptosis (Red arrows), in the form of small pyknotic nuclei and deeply acidophilic cytoplasm $(\times 200)$. (d): Subgroup IV (STZ treated diabetic-rat + glibenclamide) showing normal pancreatic structures and exocrine acini surrounding the islets of Langerhans. (e): Subgroup II (STZ treated diabetic-rat + $250 \mathrm{mg}$ ext. $/ \mathrm{kg} /$ day) showing moderate necrotic changes of the pancreas associated with mild reduction in the size and number of the islets of Langerhans. (f): Subgroup III (STZ treated diabetic-rat + $500 \mathrm{mg}$ ext. $/ \mathrm{kg} /$ day) showing a remarkable recovery as compared to the STZ treated rats, with mild degree of necrosis of islets of Langerhans. 


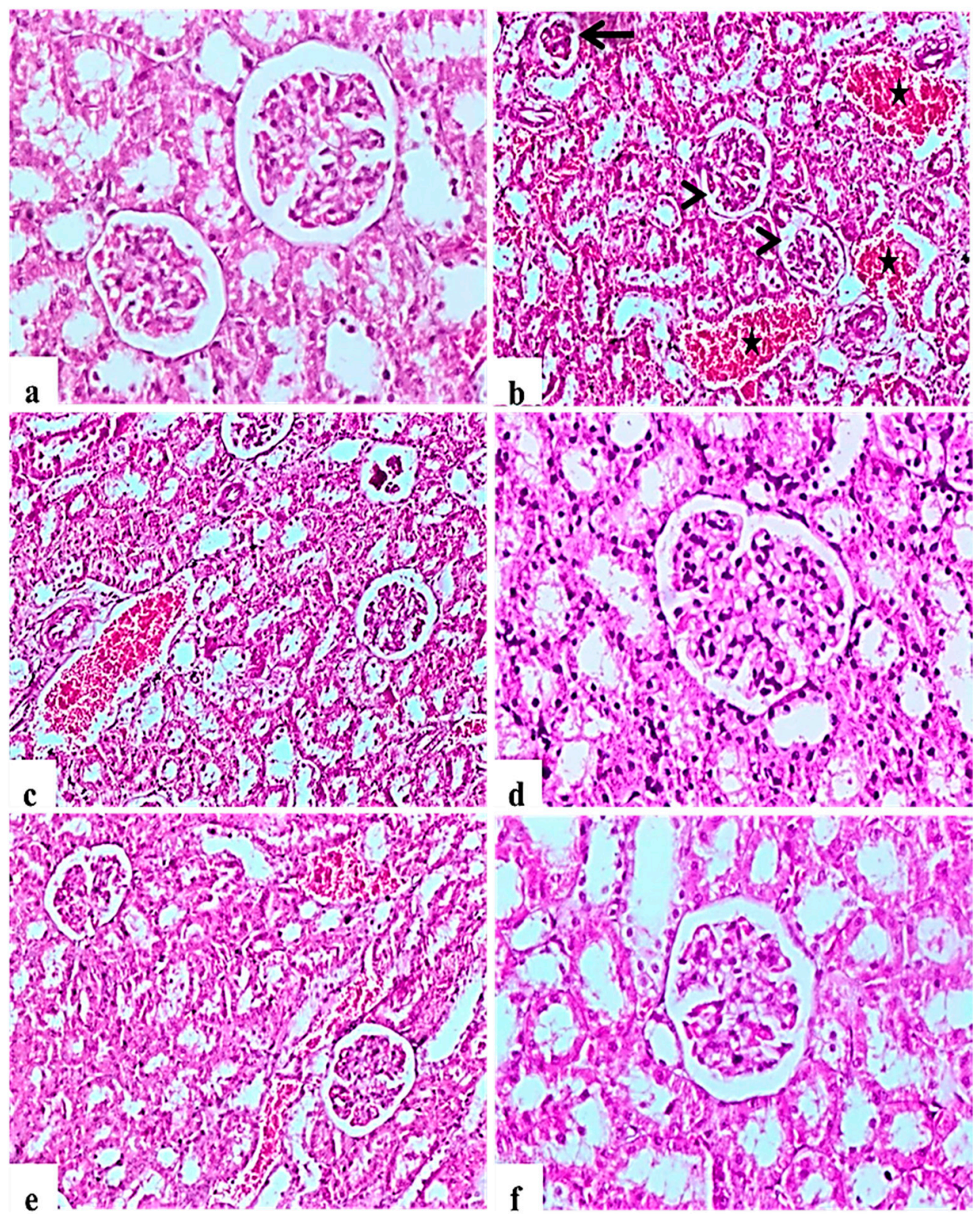

Figure 3. Histological H\&E stained sections of Kidney $(\mathbf{a}-\mathbf{e})(\times 200)(\mathbf{b}, \mathbf{d})(\times 100)$. a: control untreated rat showing normal glomerulus and renal tubules. $\mathrm{b}$ and c: Subgroup I (STZ treated diabetic-rat) rats (STZ treated diabetic-rat) showing atrophy of glomerular tuft (Black arrow), degeneration of renal tubules and increase in the Bowman' space area (Arrow heads) associated with severe hemorrhage and congestion of renal blood vessels (stars). (d): Subgroup IV (STZ treated diabetic-rat + glibenclamide) rats marked amelioration of the glomerular and tubular damage. (e): Subgroup II (STZ treated diabetic-rat $+250 \mathrm{mg}$ ext. $/ \mathrm{kg} /$ day) rats showing mild recovery of the pathological picture, still with mild congestion of renal blood vessels. (f): Subgroup III (STZ treated diabetic-rat + $500 \mathrm{mg}$ ext. $/ \mathrm{kg} /$ day) rats showing marked recovery and amelioration of the pathological picture associated with the restoration of normal renal architecture.

\subsubsection{Liver}

Examined liver sections of the negative control rats showed normal central veins; hepatocytes with the blood sinusoids were present between the hepatic cords (Figure 4a). In contrast, diabetic control rats showed mononuclear cell infiltration of the hepatic tissue, Kupffer cell activation, severe vacuolar hydropic degeneration of hepatocytes and hyperplasia of bile duct with and loss of hepatic architecture (Figure 4b), other examined sections 
showed severe congestion of central veins and blood sinusoids (Figure 4c). This picture was markedly ameliorated in the glibenclamide group showing almost normal morphology (Figure 4d). L. nudicaulis $250 \mathrm{mg}$ group showed less improvement or restoration of hepatocyte degeneration (Figure 4e), whereas L. nudicaulis $500 \mathrm{mg}$ group showed marked amelioration of the pathological picture with normal hepatic architecture.
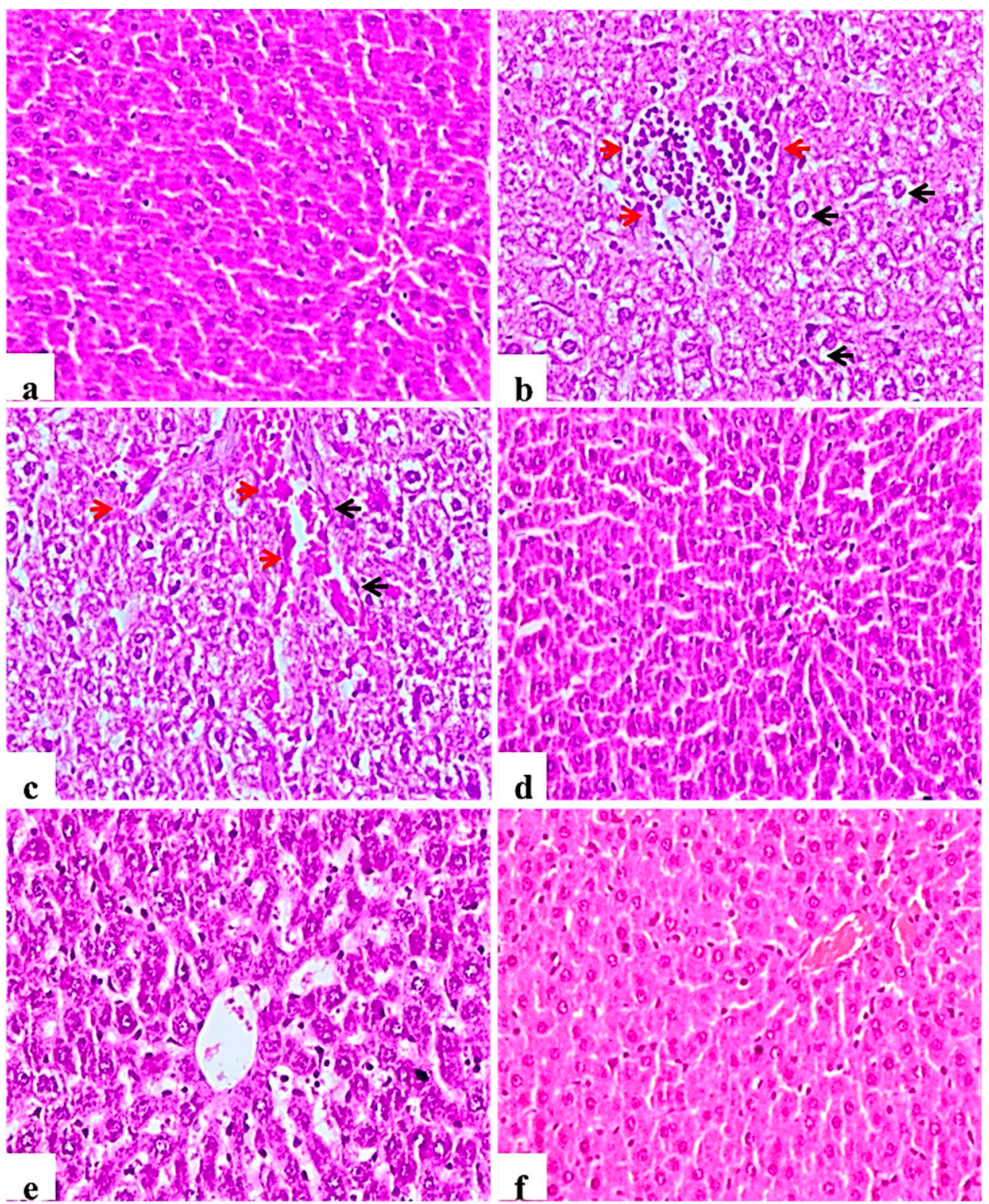

Figure 4. Histological H\&E stained sections of liver $(\times 200)$. (a): normal central veins; hepatocytes with the blood sinusoids are present between the hepatic cords. (b): Subgroup I (STZ treated diabetic-rat) rats showing mononuclear cell infiltration of the hepatic tissue (Red arrow), Kupffer cell activation, severe vacuolar hydropic degeneration of hepatocytes (Black arrow). (c): G1 rats showing Kupffer cell activation (Black arrow), severe vacuolar hydropic degeneration of hepatocytes with severe congestion of central veins and blood sinusoids (red arrow). (d): Subgroup IV (STZ treated diabetic-rat + glibenclamide) showing almost normal morphology. (e): Subgroup II (STZ treated diabetic-rat $+250 \mathrm{mg}$ ext. $/ \mathrm{kg}$ / day) showing less improvement or restoration of hepatocyte degeneration. (f): Subgroup III (STZ treated diabetic-rat + $500 \mathrm{mg}$ ext. $/ \mathrm{kg} /$ day) showing normal architecture with mild vascular congestion. 


\subsubsection{Testis}

Histopathological examination of testicular tissue from the negative control rats revealed normal architecture of the seminiferous tubules, showing a clear lumen and a normal arrangement of germinal cells, lined with series of spermatogenic cells; spermatogonia, primary spermatocytes and spermatids. Sertoli cells were observed with attached sperms. Interstitial space containing normal Leydig cells (Figure 5a).

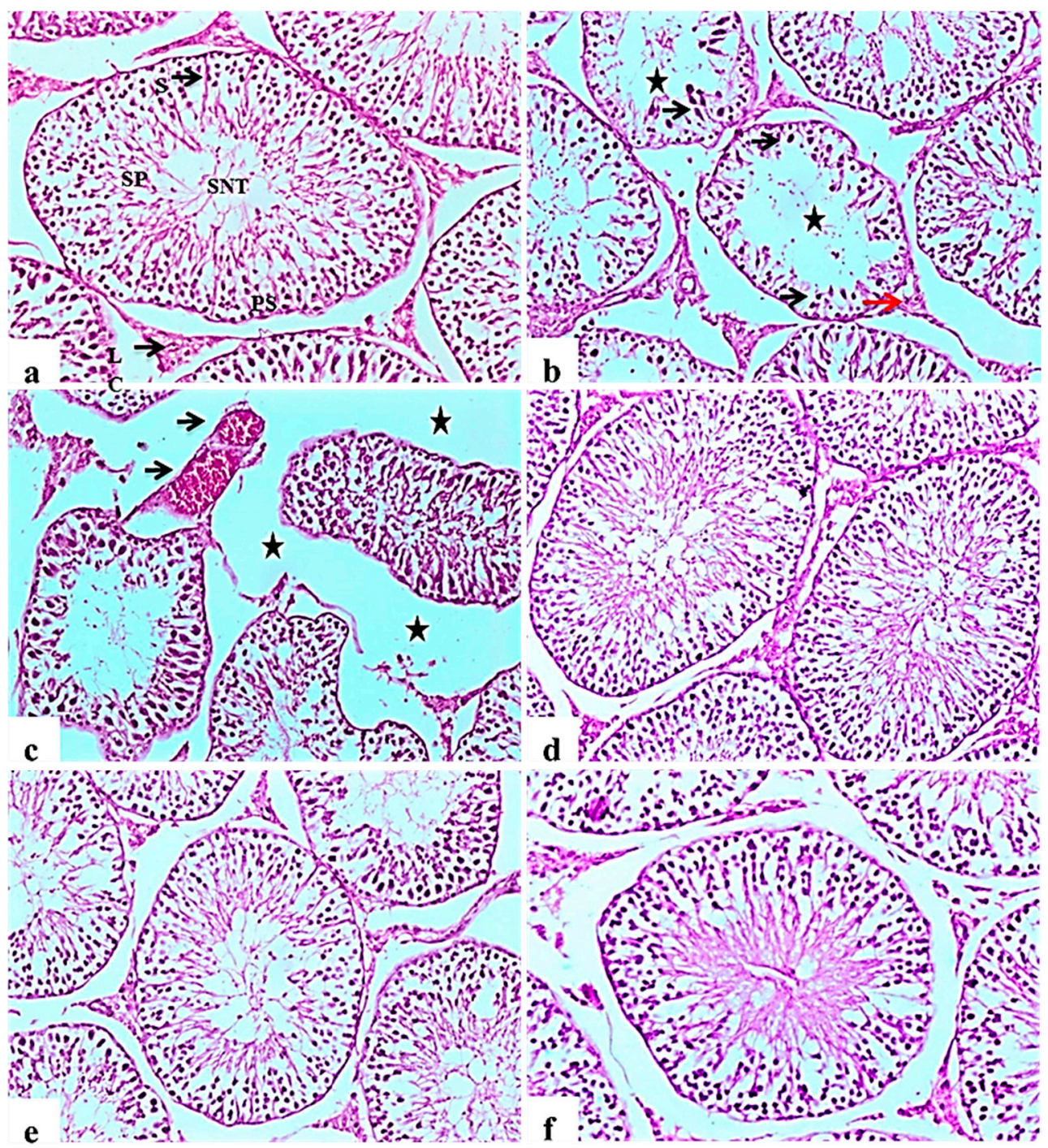

Figure 5. Histological H\&E stained sections of the testis $(\times 100)$. $(\mathbf{a})$ : control rat showing normal seminiferous tubules architecture (SNT), showing a clear lumen and a normal arrangement of cellular types, lined with series of spermatogenic cells; spermatogonia, primary spermatocytes (PS) and spermatids. Sertoli cells (S) are seen with attached sperms (SP). Interstitial space containing normal Leydig cells (LC). (b): Subgroup I (STZ treated diabetic-rat rats showing disorganization and atrophy of seminiferous tubules, absence of spermatogenesis (Star) and severe degenerative change of the lining epithelium Sertoli cells (black arrow). Leydig cells atrophy and vacuolations (red arrow). (c): showing disorganization and atrophy of seminiferous tubules, absence of spermatogenesis associated with severe interstitial oedema (Stars) and severe congestion of testicular blood vessels (black arrow). (d), (e,f): Subgroup IV (STZ treated diabetic-rat + glibenclamide, Subgroup II (STZ treated diabetic-rat + $250 \mathrm{mg}$ ext. $/ \mathrm{kg} /$ day) and Subgroup III (STZ treated diabetic-rat + $500 \mathrm{mg}$ ext. $/ \mathrm{kg} /$ day), respectively showing normal structure of seminiferous tubules with mild interstitial oedema, associated with the restoration of spermatogenic cells in most seminiferous tubules. 
Testes of diabetic control rats showed abnormal pathological alterations, including severe atrophy and disorganization of the seminiferous tubules and severe interstitial oedema, degenerative changes in spermatogenic cells lining the seminiferous tubules, associated with incomplete spermatogenesis. It was observed that the cellular levels of spermatocytes and spermatids showed reduction with the connections between cells intubated. Sertoli cells showed degeneration and necrosis, as well as Leydig cells atrophy and vacuolations (Figure 5b). Some examined sections showed severe disorganization and atrophy of seminiferous tubules accompanied by congestion of testicular blood vessels (Figure 5c). Improvement in the histopathological picture was noticed in all examined sections from diabetic rats in the glibenclamide group revealing apparent normal seminiferous tubules (Figure 5d). L. nudicaulis $250 \mathrm{mg}$ group showed a normal structure of seminiferous tubules with moderate interstitial oedema (Figure 5e). Marked improvement in the histopathological picture was noticed in L. nudicaulis $500 \mathrm{mg}$ group, where testicular sections showed restoration of spermatogenic cells in most seminiferous tubules with minimal degenerative changes (Figure 5f).

\subsection{Comprehensive Metabolites Profiling of L. nudicaulis Extract}

To identify chemical entities within the extract, ultra-high-performance liquid chromatography (UHPLC) coupled to mass spectrometry operated in positive and negative ion modes was carried out providing a comprehensive elution of analytes (Figure 6). To match the solvent polarity of $70 \%$ ethanol in water, methanol was chosen as solvent for LCMS analysis. The dielectric constant which reflects solvation power of $100 \%$ methanol was reported to be at $33.0 \varepsilon$, while the respective value of $70 \%$ ethanol was $33.5 \varepsilon$ [20]. Further, comparable total phenol contents were obtained from extraction of propolis using methanol and water/ethanol [21]. A total of 113 chromatographic peaks were observed, of which 85 were annotated with fatty acids, acyl glycerol, phenolics, terpenoids, and flavonoids as predominating classes (Table 8).

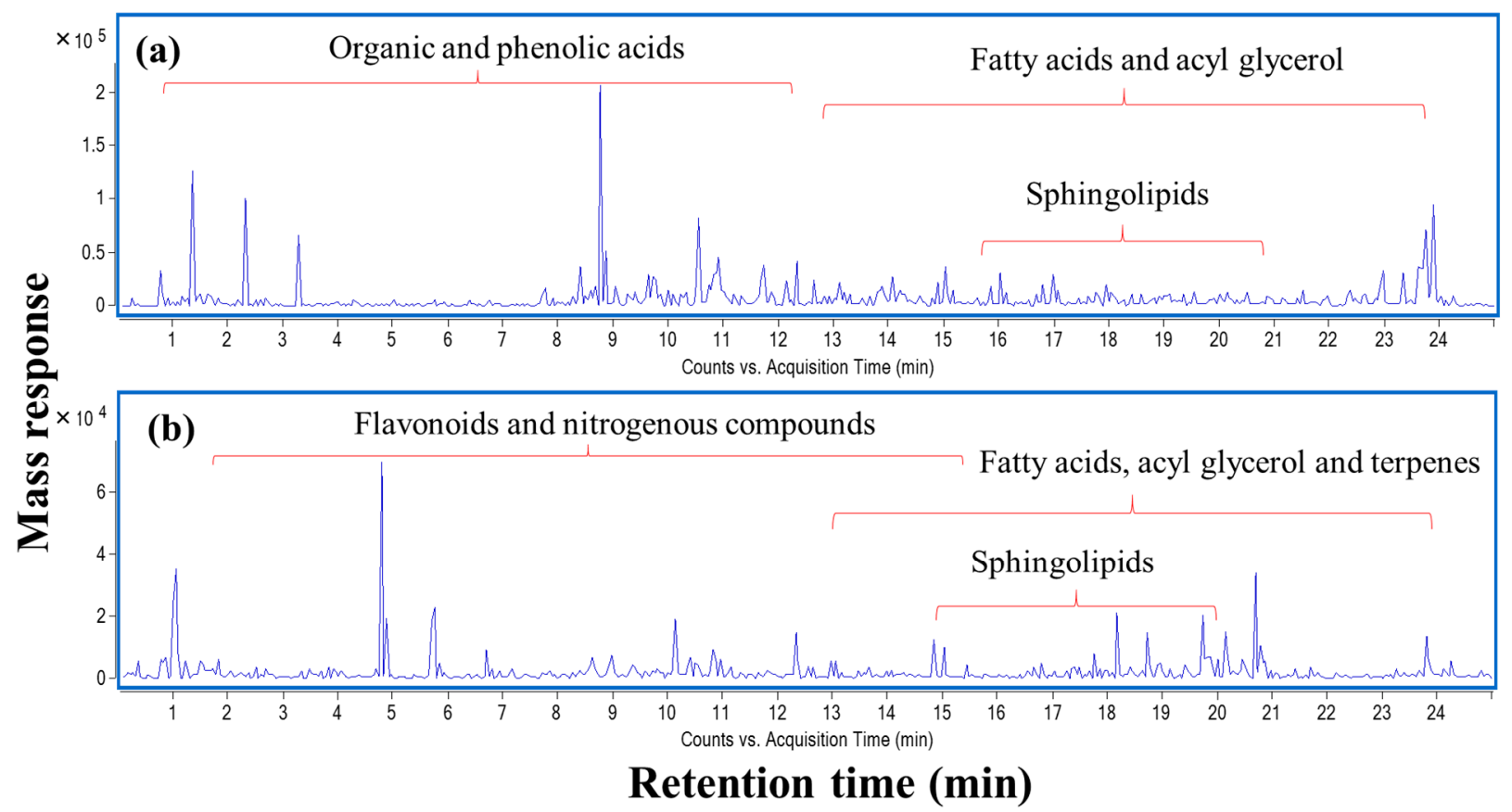

Figure 6. UPLC-qTOF-MS base peak chromatogram of L. nudicaulis ethanolic extract detected in (a) negative and (b) positive ionization modes. 
Table 8. Identified metabolites in L. nudicaulis alcoholic extract via UPLC-qTOF-MS.

\begin{tabular}{|c|c|c|c|c|c|c|c|c|}
\hline No. & RT & Formula & Name & Class & Precursor & Fragmentation & Error & Ref. \\
\hline 1 & 1.088 & $\mathrm{C}_{5} \mathrm{H}_{9} \mathrm{O}_{5}^{-}$ & Pentose & Carbohydrate & 149.0453 & $101,89,75,73$ & 1.85 & \\
\hline 2 & 1.179 & $\mathrm{C}_{7} \mathrm{H}_{11} \mathrm{O}_{6}{ }^{-}$ & Quinic acid & Organic acid & 191.0574 & $127,105,85,75$ & -7.12 & [22] \\
\hline 3 & 1.225 & $\mathrm{C}_{7} \mathrm{H}_{14} \mathrm{NO}_{2}^{+}$ & Unknwon & $\begin{array}{l}\text { Nitrogenous } \\
\text { compound }\end{array}$ & 144.1025 & $98,84,70$ & 2.47 & \\
\hline 4 & 1.271 & $\mathrm{C}_{7} \mathrm{H}_{8} \mathrm{NO}_{2}^{+}$ & Aminobenzoic acid & $\begin{array}{l}\text { Nitrogenous } \\
\text { compound }\end{array}$ & 138.0546 & $92,78,67$ & 2.39 & [23] \\
\hline 5 & 1.271 & $\mathrm{C}_{4} \mathrm{H}_{5} \mathrm{O}_{5}^{-}$ & Malic acid & Organic acid & 133.0156 & $115,75,73,71$ & -9.73 & [24] \\
\hline 6 & 1.476 & $\mathrm{C}_{10} \mathrm{H}_{7 \mathrm{O}_{4}}^{-}$ & Scopoletin & Coumarin & 191.0368 & - & 9.51 & [25] \\
\hline 7 & 1.636 & $\mathrm{C}_{11} \mathrm{H}_{16} \mathrm{NO}_{8}^{-}$ & $\begin{array}{l}\text { Deoxy-dehydro-N- } \\
\text { acetylneuraminic } \\
\text { acid }\end{array}$ & Organic acid & 290.0898 & 200,128 & -5.61 & [26] \\
\hline 8 & 1.865 & $\mathrm{C}_{12} \mathrm{H}_{19} \mathrm{~N}_{2} \mathrm{O}_{7}^{-}$ & Unknown & Pyrazine & 303.1216 & $213,123,87$ & -7.28 & [27] \\
\hline 9 & 2.642 & $\mathrm{C}_{7} \mathrm{H}_{10} \mathrm{NO}^{+}$ & Hydroxybenzylamine & $\begin{array}{l}\text { Nitrogenous } \\
\text { compound }\end{array}$ & 124.0753 & 108,94 & 5.8 & [28] \\
\hline $\begin{array}{l}10 \\
11\end{array}$ & $\begin{array}{l}2.733 \\
2.779\end{array}$ & $\begin{array}{l}\mathrm{C}_{6} \mathrm{H}_{14} \mathrm{NO}_{2}{ }^{+} \\
\mathrm{C}_{17} \mathrm{H}_{19} \mathrm{O}_{4}{ }^{+}\end{array}$ & $\begin{array}{l}\text { Leucine } \\
\text { Unknown }\end{array}$ & $\begin{array}{l}\text { Amino acid } \\
\text { Phenolic acid }\end{array}$ & $\begin{array}{c}132.1029 \\
287.127\end{array}$ & $\begin{array}{c}86,69 \\
229,193,175\end{array}$ & $\begin{array}{l}-6.85 \\
-2.73\end{array}$ & [29] \\
\hline 12 & 3.098 & $\mathrm{C}_{9} \mathrm{H}_{12} \mathrm{NO}^{+}$ & $\begin{array}{l}\text { Dimethylamino- } \\
\text { benzaldehyde }\end{array}$ & $\begin{array}{l}\text { Nitrogenous } \\
\text { compound }\end{array}$ & 150.0904 & 135,108 & 7.83 & \\
\hline 13 & 3.19 & $\mathrm{C}_{6} \mathrm{H}_{10} \mathrm{NO}_{3}^{-}$ & $\begin{array}{l}N \text {-Acetylglycine ethyl } \\
\text { ester }\end{array}$ & Amino acid & 144.067 & $102,87,71$ & 0.99 & \\
\hline 14 & 3.556 & $\mathrm{C}_{5} \mathrm{H}_{6} \mathrm{~N}_{5} \mathrm{O}^{+}$ & Guanine & Purine & 152.0576 & $135,110,94$ & -1.25 & [30] \\
\hline 15 & 3.647 & $\mathrm{C}_{19} \mathrm{H}_{23} \mathrm{O}_{6}^{+}$ & $\begin{array}{l}\text { Trihydroxy-dimethoxy- } \\
\text { dimethylflavan }\end{array}$ & Flavonoid & 347.1489 & $\begin{array}{c}332,329,284 \\
227,209\end{array}$ & -0.04 & \\
\hline $\begin{array}{l}16 \\
17\end{array}$ & $\begin{array}{l}3.693 \\
4.195\end{array}$ & $\begin{array}{c}\mathrm{C}_{10} \mathrm{H}_{12} \mathrm{~N}_{5} \mathrm{O}_{5}^{-} \\
\mathrm{C}_{7} \mathrm{H}_{7} \mathrm{O}^{+}\end{array}$ & $\begin{array}{l}\text { Guanosine } \\
\text { Benzaldehyde }\end{array}$ & $\begin{array}{l}\text { Purine } \\
\text { Aldehyde }\end{array}$ & $\begin{array}{l}282.0862 \\
107.0492\end{array}$ & $\begin{array}{c}150,133 \\
79,77\end{array}$ & $\begin{array}{c}6.4 \\
3.12\end{array}$ & [30] \\
\hline 18 & 5.064 & $\mathrm{C}_{10} \mathrm{H}_{13} \mathrm{~N}_{2} \mathrm{O}_{5}^{-}$ & Thymidine & Pyrimidine & 241.0838 & $\begin{array}{c}208,180,150 \\
131\end{array}$ & 1.01 & [30] \\
\hline 19 & 5.338 & $\mathrm{C}_{16} \mathrm{H}_{19} \mathrm{O}_{3}^{+}$ & Methylbatatasin III & Phenolic & 259.1326 & $\begin{array}{l}234,201,160 \\
136\end{array}$ & -1.04 & [31] \\
\hline 20 & 5.338 & $\mathrm{C}_{10} \mathrm{H}_{11} \mathrm{~N}_{4} \mathrm{O}_{6}{ }^{-}$ & Xanthosine & Purine & 283.0712 & $197,151,66$ & 9.86 & [32] \\
\hline 21 & 5.566 & $\mathrm{C}_{19} \mathrm{H}_{23} \mathrm{O}_{6}{ }^{+}$ & $\begin{array}{l}\text { Trihydroxy-dimethoxy- } \\
\text { dimethylflavan } \\
\text { isomer }\end{array}$ & Flavonoid & 347.1521 & $\begin{array}{l}332,330,318 \\
287,251,168\end{array}$ & 9.17 & \\
\hline 22 & 6.343 & $\mathrm{C}_{8} \mathrm{H}_{12} \mathrm{~N}^{+}$ & Phenylethylamine & $\begin{array}{l}\text { Nitrogenous } \\
\text { compound }\end{array}$ & 122.0965 & 105 & 1.45 & \\
\hline 23 & 6.846 & $\mathrm{C}_{15} \mathrm{H}_{17} \mathrm{O}_{9}{ }^{-}$ & $\begin{array}{l}\text { O-caffeoylhexose } \\
\text { Hydroxy- }\end{array}$ & Phenolic acid & 341.0912 & 179,161 & -3.31 & [33] \\
\hline 24 & 6.891 & $\mathrm{C}_{12} \mathrm{H}_{21} \mathrm{O}_{4}^{+}$ & $\begin{array}{l}\text { dihydrojasmonic } \\
\text { acid }\end{array}$ & Organic acid & 229.1443 & 170,70 & 3.77 & \\
\hline 25 & 8.034 & $\mathrm{C}_{10} \mathrm{H}_{13} \mathrm{~N}_{2} \mathrm{O}_{4}^{-}$ & Unknwon nitrogenous & Nitrogenous & 225.0891 & $\begin{array}{c}210,181,165 \\
139\end{array}$ & -5.16 & \\
\hline 26 & 8.125 & $\mathrm{C}_{10} \mathrm{H}_{12} \mathrm{~N}_{5} \mathrm{O}^{-}$ & Zeatin & Purine & 218.1048 & $\begin{array}{c}204,177,146, \\
137\end{array}$ & 0.44 & [34] \\
\hline 27 & 8.216 & $\mathrm{C}_{17} \mathrm{H}_{19} \mathrm{O}_{3}{ }^{+}$ & $\begin{array}{l}\text { Hydroxy-methoxy- } \\
\text { methylflavan }\end{array}$ & Flavonoid & 271.1311 & $\begin{array}{c}256,228,193 \\
177,147,137 \\
121\end{array}$ & -6.53 & \\
\hline 28 & 8.262 & $\mathrm{C}_{18} \mathrm{H}_{19} \mathrm{O}_{2}{ }^{+}$ & $\begin{array}{l}\text { Phenylpropyl } \\
\text { cinnamate }\end{array}$ & Ester & 267.1374 & $\begin{array}{c}189,147,120 \\
86\end{array}$ & -2.08 & \\
\hline 29 & 8.308 & $\mathrm{C}_{14} \mathrm{H}_{15} \mathrm{O}^{+}$ & Phenethylphenol & Phenolic & 199.1099 & 135,109 & 2.88 & \\
\hline 30 & 8.354 & $\mathrm{C}_{9} \mathrm{H}_{11} \mathrm{O}_{3}{ }^{+}$ & $\begin{array}{l}\text { Methoxyphenylacetic } \\
\text { acid }\end{array}$ & Phenolic & 167.0702 & $123,109,78$ & -0.42 & [35] \\
\hline 31 & 8.765 & $\mathrm{C}_{13} \mathrm{H}_{9 \mathrm{O}_{9}}{ }^{-}$ & $\begin{array}{l}\text { Caffeoyl-O- } \\
\text { dihydroxymaleic } \\
\text { acid }\end{array}$ & Phenolic acid & 309.0283 & $179,135,133$ & -9.93 & \\
\hline 32 & 8.811 & $\mathrm{C}_{16} \mathrm{H}_{17} \mathrm{O}_{9}{ }^{-}$ & $O$-Caffeoylquinic acid & Phenolic acid & 353.0911 & 191,179 & 9.32 & [15] \\
\hline 33 & 8.856 & $\mathrm{C}_{13} \mathrm{H}_{11} \mathrm{O}_{9}^{-}$ & Caffeoyl tartaric acid & Phenolic acid & 311.0438 & $179,149,135$ & -9.73 & [36] \\
\hline 34 & 8.902 & $\mathrm{C}_{7} \mathrm{H}_{5} \mathrm{O}_{5}^{-}$ & Gallic acid & Phenolic acid & 169.0161 & $\begin{array}{c}151,125,107 \\
95\end{array}$ & -9.24 & [37] \\
\hline 35 & 8.993 & $\mathrm{C}_{9} \mathrm{H}_{8} \mathrm{NO}^{+}$ & Unknwon & Aldehyde & 146.0608 & $118,91,77$ & -3.73 & \\
\hline 36 & 9.176 & $\mathrm{C}_{20} \mathrm{H}_{19} \mathrm{O}_{2}^{+}$ & Unknown & - & 291.1363 & $\begin{array}{c}205,190,141 \\
128\end{array}$ & -0.26 & \\
\hline 37 & 9.359 & $\mathrm{C}_{13} \mathrm{H}_{11} \mathrm{O}_{8}^{-}$ & $\begin{array}{c}p \text {-coumaroyltartaric } \\
\text { acid }\end{array}$ & Phenolic acid & 295.0488 & $\begin{array}{c}251,163,119 \\
87\end{array}$ & 9.69 & [38] \\
\hline 38 & 9.404 & $\mathrm{C}_{10} \mathrm{H}_{10} \mathrm{~N}^{+}$ & Unknown & $\begin{array}{l}\text { Nitrogenous } \\
\text { compound }\end{array}$ & 144.0811 & $\begin{array}{c}127,116,103, \\
91\end{array}$ & -2.61 & \\
\hline 39 & 9.633 & $\mathrm{C}_{14} \mathrm{H}_{13} \mathrm{O}_{9}^{-}$ & Feruloyl-O-tartaric acid & Phenolic acid & 325.0599 & 193,134 & -9.13 & [39] \\
\hline 40 & 9.953 & $\mathrm{C}_{12} \mathrm{H}_{17} \mathrm{O}_{4}^{-}$ & Hydroxyjasmonic acid & Organic acid & 225.1157 & $165,137,97,81$ & -9.87 & \\
\hline
\end{tabular}


Table 8. Cont.

\begin{tabular}{|c|c|c|c|c|c|c|c|c|}
\hline No. & RT & Formula & Name & Class & Precursor & Fragmentation & Error & Ref. \\
\hline 41 & 9.999 & $\mathrm{C}_{9} \mathrm{H}_{5} \mathrm{O}_{4}^{-}$ & Caffeic acid quinone & Phenolic acid & 177.0209 & $\begin{array}{l}162,149 \\
135,121\end{array}$ & -8.28 & \\
\hline 42 & 10.09 & $\mathrm{C}_{12} \mathrm{H}_{12} \mathrm{NO}_{5}^{-}$ & $p$-Coumaroyl-serine & Phenolic acid & 250.0745 & $\begin{array}{c}207,161,132 \\
115\end{array}$ & -9.12 & \\
\hline 43 & 10.227 & $\mathrm{C}_{8} \mathrm{H}_{7} \mathrm{~N}_{4} \mathrm{O}^{-}$ & Unknown & $\begin{array}{l}\text { Nitrogenous } \\
\text { compound }\end{array}$ & 175.0631 & $\begin{array}{c}133,105,89 \\
77\end{array}$ & -3.26 & \\
\hline 44 & 10.273 & $\mathrm{C}_{9} \mathrm{H}_{7} \mathrm{O}_{4}^{-}$ & Caffeic acid & Phenolic acid & 179.0366 & $\begin{array}{c}135,124,107 \\
93\end{array}$ & 5.95 & [40] \\
\hline 45 & 10.501 & $\mathrm{C}_{11} \mathrm{H}_{12} \mathrm{NO}_{3}^{-}$ & $\begin{array}{c}N \text {-Acetyl-L- } \\
\text { phenylalanine }\end{array}$ & Amino acid & 206.0835 & $\begin{array}{c}164,147,103 \\
91\end{array}$ & -6 & [41] \\
\hline 46 & 10.867 & $\mathrm{C}_{10} \mathrm{H}_{17} \mathrm{~N}_{2} \mathrm{O}_{3} \mathrm{~S}^{-}$ & Prolyl-methionine & Amino acid & 245.0961 & $\begin{array}{c}203,186,159 \\
142\end{array}$ & 0.27 & \\
\hline 47 & 10.913 & $\mathrm{C}_{24} \mathrm{H}_{35} \mathrm{~N}_{8} \mathrm{OS}_{4}^{-}$ & Unknown & - & 579.1791 & $\begin{array}{c}254,203 \\
116,72\end{array}$ & 0.75 & \\
\hline 48 & 11.232 & $\mathrm{C}_{25} \mathrm{H}_{23} \mathrm{O}_{12}^{-}$ & $\begin{array}{l}\text { Scopoletin-7-O- } \\
\text { dihexoside }\end{array}$ & Coumarin & 515.1237 & $\begin{array}{c}353,191,179 \\
173\end{array}$ & 8.15 & [42] \\
\hline 49 & 11.552 & $\mathrm{C}_{9} \mathrm{H}_{15} \mathrm{O}_{4}^{-}$ & Nonanedioic acid & Organic acid & 187.0995 & $\begin{array}{c}170,125,97 \\
87\end{array}$ & 7.29 & [43] \\
\hline 50 & 11.849 & $\mathrm{C}_{10} \mathrm{H}_{11} \mathrm{O}_{4}^{+}$ & Methyl caffeate & Phenolic acid & 195.0657 & $\begin{array}{c}177,163,150 \\
145\end{array}$ & -2.98 & [44] \\
\hline 51 & 12.009 & $\mathrm{C}_{20} \mathrm{H}_{31} \mathrm{O}_{6}^{+}$ & Unknown & - & 367.2151 & $\begin{array}{c}349,325,204 \\
112\end{array}$ & 9.76 & \\
\hline 52 & 12.329 & $\mathrm{C}_{15} \mathrm{H}_{11} \mathrm{O}_{6}^{+}$ & Kaempferol & Flavonoid & 287.0567 & $153,135,93$ & 5.87 & [45] \\
\hline 53 & 12.512 & $\mathrm{C}_{11} \mathrm{H}_{17} \mathrm{O}_{3}^{+}$ & $\begin{array}{l}\text { Hydroxybutyl- } \\
\text { methoxy-phenol }\end{array}$ & Phenolic & 197.1188 & $\begin{array}{c}180,166,153 \\
141\end{array}$ & -9.75 & \\
\hline 54 & 12.74 & $\mathrm{C}_{11} \mathrm{H}_{11} \mathrm{O}_{4}^{-}$ & Unknown & Phenolic acid & 207.068 & $179,161,135$ & 8.29 & \\
\hline 55 & 12.786 & $\mathrm{C}_{13} \mathrm{H}_{23} \mathrm{O}_{2}{ }^{+}$ & Tridecadienoic acid & Fatty acid & 211.1694 & $\begin{array}{c}151,135,83 \\
67\end{array}$ & -0.79 & \\
\hline 56 & 13.06 & $\mathrm{C}_{15} \mathrm{H}_{11} \mathrm{O}_{5}^{+}$ & Apigenin & Flavonoid & 271.0627 & $153,131,95$ & 9.59 & [46] \\
\hline 57 & 13.106 & $\mathrm{C}_{18} \mathrm{H}_{35} \mathrm{O}_{5}{ }^{+}$ & $\begin{array}{l}\text { Trihydroxy- } \\
\text { octadecenoic } \\
\text { acid }\end{array}$ & Fatty acid & 331.2476 & $\begin{array}{c}288,244,175 \\
69\end{array}$ & -0.9 & [47] \\
\hline 58 & 13.151 & $\mathrm{C}_{18} \mathrm{H}_{33} \mathrm{O}_{5}^{-}$ & $\begin{array}{l}\text { Trihydroxyoctadecenoic } \\
\text { acid isomer }\end{array}$ & Fatty acid & 329.2364 & $311,201,171$ & -9.19 & [47] \\
\hline 59 & 13.288 & $\mathrm{C}_{13} \mathrm{H}_{21} \mathrm{O}_{2}^{+}$ & Tridecatrienoic acid & Fatty acid & 209.1542 & $163,93,79,71$ & -3.85 & \\
\hline 60 & 13.334 & $\mathrm{C}_{15} \mathrm{H}_{23} \mathrm{O}_{2}^{+}$ & Unknown terpene & Terpene & 235.1712 & $\begin{array}{c}219,161,121 \\
93\end{array}$ & -5.11 & \\
\hline 61 & 13.38 & $\mathrm{C}_{15} \mathrm{H}_{23} \mathrm{O}^{+}$ & Unknown terpene & Terpene & 219.175 & $\begin{array}{c}204,175,121 \\
79\end{array}$ & -1.84 & \\
\hline 62 & 13.562 & $\mathrm{C}_{20} \mathrm{H}_{33} \mathrm{O}_{5}^{+}$ & $\begin{array}{l}\text { Trihydroxyicosa- } \\
\text { tetraenoic acid } \\
\text { (lipoxin) }\end{array}$ & Fatty acid & 353.2317 & $\begin{array}{c}308,277,222 \\
199\end{array}$ & -1.55 & \\
\hline 63 & 13.7 & $\mathrm{C}_{18} \mathrm{H}_{29} \mathrm{O}_{4}^{+}$ & $\begin{array}{l}\text { Hydroxy-oxo- } \\
\text { octadecatrienoic } \\
\text { acid }\end{array}$ & Fatty acid & 309.207 & $\begin{array}{l}292,273,219 \\
165\end{array}$ & 1.31 & [48] \\
\hline 64 & 13.837 & $\mathrm{C}_{18} \mathrm{H}_{27} \mathrm{O}_{3}{ }^{+}$ & Unknown & Terpene & 291.1942 & $\begin{array}{c}204,177,133 \\
119\end{array}$ & 5.55 & \\
\hline 65 & 13.882 & $\mathrm{C}_{16} \mathrm{H}_{29} \mathrm{O}_{2}{ }^{+}$ & $\begin{array}{l}\text { Hexadecadienoic } \\
\text { acid }\end{array}$ & Fatty acid & 253.2169 & $\begin{array}{c}237,209,193 \\
174\end{array}$ & -1.34 & [49] \\
\hline 66 & 14.157 & $\mathrm{C}_{20} \mathrm{H}_{31} \mathrm{O}_{5}^{+}$ & $\begin{array}{c}\text { Dihydroxy-oxoicosa- } \\
\text { tetraenoic } \\
\text { acid }\end{array}$ & Fatty acid & 351.2159 & $\begin{array}{c}334,149,106 \\
81\end{array}$ & -1.99 & \\
\hline 67 & 14.385 & $\mathrm{C}_{45} \mathrm{H}_{83} \mathrm{O}_{16} \mathrm{P}_{2}{ }^{-}$ & $\begin{array}{l}\text { Phosphatidylinositol } \\
\text { phosphate } \\
(18: 0 / 18: 2)\end{array}$ & Acyl glycerol & 941.5213 & $\begin{array}{c}880,471,394 \\
259\end{array}$ & 5.43 & \\
\hline
\end{tabular}


Table 8. Cont.

\begin{tabular}{|c|c|c|c|c|c|c|c|c|}
\hline No. & RT & Formula & Name & Class & Precursor & Fragmentation & Error & Ref. \\
\hline 68 & 14.431 & $\mathrm{C}_{15} \mathrm{H}_{13} \mathrm{O}_{3+}$ & Unknown & Terpene & 241.0856 & $\begin{array}{c}227,211,180 \\
157\end{array}$ & -1.33 & \\
\hline 69 & 14.705 & $\mathrm{C}_{18} \mathrm{H}_{27} \mathrm{O}_{2}{ }^{+}$ & Unknown & Terpene & 275.2024 & $\begin{array}{c}\text { 171, 147 } \\
119,79\end{array}$ & -6.62 & \\
\hline 70 & 14.751 & $\mathrm{C}_{20} \mathrm{H}_{29} \mathrm{O}_{4}^{+}$ & Unknown & - & 333.2056 & $\begin{array}{c}307,188,135 \\
87\end{array}$ & -1.3 & \\
\hline 71 & 14.842 & $\mathrm{C}_{21} \mathrm{H}_{23} \mathrm{O}_{8}^{+}$ & Hexamethoxyflavone & Flavonoid & 403.1394 & $\begin{array}{c}388,373,212 \\
183\end{array}$ & 1.62 & [50] \\
\hline 72 & 14.933 & $\mathrm{C}_{17} \mathrm{H}_{27} \mathrm{O}_{5}^{-}$ & $\begin{array}{l}\text { Glycerol-hydroxy- } \\
\text { tetradecatrienoate }\end{array}$ & Acyl glycerol & 311.1895 & $267,179,135$ & 9.96 & \\
\hline 73 & 14.979 & $\mathrm{C}_{18} \mathrm{H}_{27} \mathrm{O}_{3}^{+}$ & $\begin{array}{c}\text { Oxo- } \\
\text { octadecatetraenoic } \\
\text { acid }\end{array}$ & Fatty acid & 291.1965 & $\begin{array}{c}209,157,133 \\
121\end{array}$ & -0.64 & \\
\hline 74 & 15.208 & $\mathrm{C}_{18} \mathrm{H}_{31} \mathrm{O}_{4}^{-}$ & $\begin{array}{c}\text { Dihydroxy- } \\
\text { octadecadienoic } \\
\text { acid }\end{array}$ & Fatty acid & 311.2245 & $\begin{array}{c}267,179,135 \\
87\end{array}$ & -6.15 & [47] \\
\hline 75 & 15.436 & $\mathrm{C}_{20} \mathrm{H}_{21} \mathrm{O}_{7}^{+}$ & Pentamethoxyflavone & Flavonoid & 373.1281 & $\begin{array}{c}358,343,312 \\
266,197\end{array}$ & -0.21 & [50] \\
\hline 76 & 15.619 & $\mathrm{C}_{18} \mathrm{H}_{40} \mathrm{NO}_{3}{ }^{+}$ & $\begin{array}{c}\text { Amino- } \\
\text { octadecanetriol }\end{array}$ & Sphingolipid & 318.2982 & $\begin{array}{c}303,242,150 \\
62\end{array}$ & -6.5 & \\
\hline 77 & 15.847 & $\mathrm{C}_{13} \mathrm{H}_{23} \mathrm{O}_{3}{ }^{+}$ & $\begin{array}{c}\text { Methyl } \\
\text { dihydrojasmonate }\end{array}$ & Oxylipid & 227.1645 & $\begin{array}{c}212,183,141, \\
125\end{array}$ & 1.44 & \\
\hline 78 & 15.893 & $\mathrm{C}_{20} \mathrm{H}_{33} \mathrm{O}_{4}{ }^{+}$ & Unknown & Terpene & 337.2368 & $\begin{array}{c}293,232,195 \\
168\end{array}$ & -1.58 & \\
\hline 79 & 15.938 & $\mathrm{C}_{18} \mathrm{H}_{29} \mathrm{O}_{3}{ }^{+}$ & $\begin{array}{l}\text { Oxophytodienoic } \\
\text { acid }\end{array}$ & Oxylipid & 293.2117 & $\begin{array}{c}238,151,145 \\
101\end{array}$ & -0.02 & \\
\hline 80 & 15.984 & $\mathrm{C}_{19} \mathrm{H}_{27} \mathrm{O}_{4}^{+}$ & Unknown & Terpene & 319.1893 & $\begin{array}{c}303,235,165 \\
105\end{array}$ & -3.4 & \\
\hline 81 & 16.304 & $\mathrm{C}_{20} \mathrm{H}_{31} \mathrm{O}_{4}^{+}$ & Unknown & - & 335.2218 & $\begin{array}{c}318 \\
273,158,83\end{array}$ & 0.34 & \\
\hline 82 & 16.578 & $\mathrm{C}_{18} \mathrm{H}_{29} \mathrm{O}_{3}^{-}$ & $\begin{array}{l}\text { Hydroxylinolenic } \\
\text { acid }\end{array}$ & Fatty acid & 293.215 & $\begin{array}{c}275,249,233 \\
183\end{array}$ & -9.51 & \\
\hline 83 & 16.578 & $\mathrm{C}_{18} \mathrm{H}_{29} \mathrm{O}_{2}{ }^{+}$ & Unknown & Terpene & 277.2164 & $\begin{array}{c}149,121,107 \\
93\end{array}$ & 0.85 & \\
\hline 84 & 16.67 & $\mathrm{C}_{18} \mathrm{H}_{27} \mathrm{O}_{2}{ }^{+}$ & Unknown & Terpene & 275.2015 & $\begin{array}{c}149,135,121 \\
93\end{array}$ & -2.45 & \\
\hline 85 & 16.761 & $\mathrm{C}_{20} \mathrm{H}_{29} \mathrm{O}_{3}{ }^{+}$ & Unknown & Terpene & 317.2088 & $\begin{array}{c}299,187,164 \\
110\end{array}$ & -7.31 & \\
\hline 86 & 16.898 & $\mathrm{C}_{18} \mathrm{H}_{29} \mathrm{O}_{3}^{+}$ & $\begin{array}{l}\text { Oxooctadeca- } \\
\text { trienoic } \\
\text { acid }\end{array}$ & Fatty acid & 293.2126 & $\begin{array}{c}275,248,125 \\
93\end{array}$ & -5.77 & \\
\hline 87 & 17.081 & $\mathrm{C}_{13} \mathrm{H}_{25} \mathrm{O}_{3}{ }^{+}$ & $\begin{array}{c}\text { Hydroxy- } \\
\text { tridecenoic } \\
\text { acid }\end{array}$ & Fatty acid & 229.181 & $155,109,67$ & 0.45 & \\
\hline 88 & 17.172 & $\mathrm{C}_{18} \mathrm{H}_{37} \mathrm{O}_{6}^{+}$ & $\begin{array}{c}\text { Tetrahydroxy- } \\
\text { octadecanoic acid } \\
\text { (saturated) }\end{array}$ & Fatty acid & 349.2602 & $\begin{array}{c}306,277,190 \\
83\end{array}$ & 4.96 & [51] \\
\hline 89 & 17.264 & $\mathrm{C}_{18} \mathrm{H}_{31} \mathrm{O}_{2}^{+}$ & $\begin{array}{l}\text { Octadeca-trienoic } \\
\text { acid (Linolenic acid) }\end{array}$ & Fatty acid & 279.2332 & $95,81,67$ & -7.17 & \\
\hline 90 & 17.538 & $\mathrm{C}_{22} \mathrm{H}_{35} \mathrm{O}_{3}{ }^{+}$ & Unknown & Terpene & 347.2564 & $\begin{array}{c}276,263,174 \\
163\end{array}$ & 2.03 & \\
\hline 91 & 17.583 & $\mathrm{C}_{18} \mathrm{H}_{29} \mathrm{O}_{2}{ }^{+}$ & Unknown & Terpene & 277.2172 & $\begin{array}{c}150,121,95 \\
81\end{array}$ & -1.14 & \\
\hline 92 & 17.629 & $\mathrm{C}_{22} \mathrm{H}_{37} \mathrm{O}_{3}{ }^{+}$ & Unknown & Terpene & 349.2737 & $\begin{array}{c}315,275,214 \\
165\end{array}$ & -0.06 & \\
\hline 93 & 17.995 & $\mathrm{C}_{24} \mathrm{H}_{41} \mathrm{O}_{5}{ }^{+}$ & Unknown & - & 409.294 & $\begin{array}{c}391,353,123 \\
86\end{array}$ & -2.07 & \\
\hline
\end{tabular}


Table 8. Cont.

\begin{tabular}{|c|c|c|c|c|c|c|c|c|}
\hline No. & RT & Formula & Name & Class & Precursor & Fragmentation & Error & Ref. \\
\hline 94 & 18.132 & $\mathrm{C}_{18} \mathrm{H}_{21} \mathrm{O}_{4}^{+}$ & Unknown & Terpene & 301.1426 & $\begin{array}{c}214,182,135 \\
93\end{array}$ & -2.77 & \\
\hline 95 & 18.269 & $\mathrm{C}_{18} \mathrm{H}_{31} \mathrm{O}_{3}^{-}$ & $\begin{array}{l}\text { Hydroxyolinoleic } \\
\text { acid }\end{array}$ & Fatty acid & 295.2303 & $\begin{array}{c}277,233,195 \\
183\end{array}$ & -8.22 & \\
\hline 96 & 18.863 & $\mathrm{C}_{25} \mathrm{H}_{48} \mathrm{O}_{12} \mathrm{P}^{-}$ & $\begin{array}{c}\text { Phosphoinositol } \\
(16: 0 / 0: 0)\end{array}$ & Acyl glycerol & 571.2935 & $\begin{array}{c}434,409,380 \\
315\end{array}$ & 8.07 & \\
\hline 97 & 19 & $\mathrm{C}_{24} \mathrm{H}_{39} \mathrm{O}_{4}^{+}$ & Unknown & Terpene & 391.283 & $373,187,85$ & -3.28 & \\
\hline 98 & 19.183 & $\mathrm{C}_{19} \mathrm{H}_{33} \mathrm{O}_{2}^{+}$ & $\begin{array}{l}\text { Methyl-octadeca- } \\
\text { trienoate }\end{array}$ & Fatty acid & 293.2487 & $248,169,95$ & -3.5 & [52] \\
\hline 99 & 19.228 & $\mathrm{C}_{22} \mathrm{H}_{35} \mathrm{O}_{2}^{+}$ & $\begin{array}{l}\text { Docosapentaenoic } \\
\text { acid }\end{array}$ & Fatty acid & 331.266 & $\begin{array}{c}275,235,146 \\
67\end{array}$ & 8.58 & \\
\hline 100 & 19.594 & $\mathrm{C}_{28} \mathrm{H}_{47} \mathrm{O}_{4}^{+}$ & Unknown & Sterol & 447.3459 & $\begin{array}{c}429,359,206 \\
149\end{array}$ & -2.2 & \\
\hline 101 & 20.096 & $\mathrm{C}_{24} \mathrm{H}_{37} \mathrm{O}_{3}{ }^{+}$ & Unknown & Oxylipid & 373.2719 & $\begin{array}{c}356, \\
329,284,235\end{array}$ & -4.8 & \\
\hline 102 & 20.234 & $\mathrm{C}_{43} \mathrm{H} 79 \mathrm{NO}_{10} \mathrm{P}^{-}$ & $\begin{array}{l}\text { Phosphoserine } \\
\text { (19:0/18:2) }\end{array}$ & Acyl glycerol & 800.5521 & 741,227 & 9.23 & \\
\hline 103 & 20.371 & $\mathrm{C}_{16} \mathrm{H}_{31} \mathrm{O}_{3}^{-}$ & Hydroxypalmitate & Fatty acid & 271.2302 & $\begin{array}{c}227,225,195 \\
151\end{array}$ & -7.7 & \\
\hline 104 & 20.417 & $\mathrm{C}_{43} \mathrm{H}_{76} \mathrm{O}_{12} \mathrm{P}^{-}$ & $\begin{array}{l}\text { Phosphoinositol } \\
\text { (P-16:0/18:4) }\end{array}$ & Acyl glycerol & 815.5059 & $\begin{array}{c}758,475,428 \\
281\end{array}$ & -2.56 & \\
\hline 105 & 20.599 & $\mathrm{C}_{45} \mathrm{H}_{81} \mathrm{NO}_{10} \mathrm{P}^{-}$ & $\begin{array}{c}\text { Phosphoserine } \\
(19: 1 / 20: 2)\end{array}$ & Acyl glycerol & 826.566 & $767,477,279$ & 6.82 & \\
\hline 106 & 20.691 & $\mathrm{C}_{34} \mathrm{H}_{68} \mathrm{NO}_{5}^{-}$ & $\begin{array}{c}\text { Ceramide } \\
(\mathrm{t} 18: 0 / 16: 0(2 \mathrm{OH}))\end{array}$ & Sphingolipid & 570.5157 & 314,255 & 9.46 & [53] \\
\hline 107 & 21.056 & $\mathrm{C}_{30} \mathrm{H}_{49} \mathrm{O}_{2}^{+}$ & Unknown & Sterol & 441.369 & $\begin{array}{c}423,361 \\
259,219\end{array}$ & -8.39 & \\
\hline 108 & 22.472 & $\mathrm{C}_{42} \mathrm{H}_{84} \mathrm{NO}_{5}^{+}$ & $\begin{array}{c}\text { Ceramide } \\
(\mathrm{t} 18: 1 / 24: 0(2 \mathrm{OH}))\end{array}$ & Sphingolipid & 682.6342 & $\begin{array}{c}665,427,372 \\
162,74\end{array}$ & -0.29 & [53] \\
\hline 109 & 22.747 & $\mathrm{C}_{48} \mathrm{H}_{92} \mathrm{NO}_{10}{ }^{-}$ & Iotroridoside & Glycosphingolipid & 842.6782 & $438,179,89$ & 6.56 & [54] \\
\hline 110 & 22.838 & $\mathrm{C}_{43} \mathrm{H}_{77} \mathrm{O}_{13} \mathrm{P}^{-}$ & $\begin{array}{c}\text { Phosphatidylinositol } \\
(16: 0 / 18: 2)\end{array}$ & Acyl glycerol & 832.5031 & $520,366,273$ & -9.16 & \\
\hline 111 & 22.93 & $\mathrm{C}_{43} \mathrm{H}_{74} \mathrm{O}_{13} \mathrm{P}^{-}$ & $\begin{array}{c}\text { Phosphatidylinositol } \\
\text { (14:0/20:4) }\end{array}$ & Acyl glycerol & 829.4852 & $787,225,89$ & -2.47 & \\
\hline 112 & 23.295 & $\mathrm{C}_{45} \mathrm{H}_{74} \mathrm{O}_{13} \mathrm{P}^{-}$ & $\begin{array}{c}\text { Phosphatidylinositol } \\
(16: 1 / 20: 5)\end{array}$ & Acyl glycerol & 853.4843 & $610,339,108$ & -3.45 & \\
\hline 113 & 23.706 & $\mathrm{C}_{43} \mathrm{H}_{76} \mathrm{O}_{13} \mathrm{P}^{-}$ & $\begin{array}{c}\text { Phosphatidylinositol } \\
\text { (20:1/14:1) }\end{array}$ & Acyl glycerol & 831.5004 & $772,459,80$ & -3.01 & \\
\hline
\end{tabular}

\subsubsection{Flavonoids}

Flavonoids are ubiquitous secondary metabolites with known antihyperlipidemic, antitumor, antidiabetic and antioxidant effects [55] Methoxylated flavonoids were characterized by methyl losses (-15 amu) as observed in hydroxymethoxymethylflavan (peak 27; $m / z 271.1311, \mathrm{C}_{17} \mathrm{H}_{19} \mathrm{O}_{3}{ }^{+}$) yielding fragment ion at $m / z 256$. Likewise, a more lypophilic flavone conjugate was found in the peak $75[\mathrm{M}+\mathrm{H}]^{+} \mathrm{m} / z 373.1281$ with fragment ions at $m / z 358[\mathrm{M}+\mathrm{H}-15]^{+}$and $343[\mathrm{M}+\mathrm{H}-30]^{+}$annotated as pentamethoxyflavone. Additionally, peak 71 revealed characteristic product ions at $\mathrm{m} / \mathrm{z} 212$ and 183 ascribed to RDA fission suggesting a dimethoxy B ring and identified as hexamethoxyflavone. Conversely, two free flavonoid aglycones were present in peaks 52 and 56, corresponding to kaempferol $\left(m / z 287.0567, \mathrm{C}_{15} \mathrm{H}_{11} \mathrm{O}_{6}{ }^{+}\right)$and apigenin $\left(m / z 271.0627, \mathrm{C}_{15} \mathrm{H}_{11} \mathrm{O}_{5}{ }^{+}\right)$, respectively.

\subsubsection{Simple Phenolics}

Simple phenolics were the second dominant class in L. nudicaulis after fatty acids / sphingolipids. Phenolic acids viz., caffeic acid (peak 44; $\mathrm{m} / \mathrm{z} 179.0366$ ) and gallic acid (peak 34; $\mathrm{m} / \mathrm{z}$ 169.0161) displayed a characteristic loss of $44 \mathrm{amu}$ owing to the loss of 
$\mathrm{CO}_{2}$ while caffeic acid esters exhibited a fragment ion at $\mathrm{m} / \mathrm{z} 179$ in negative ion mode corresponding to the caffeoyl moiety as indicated in caffeoyl tartaric acid (peak 33; $\mathrm{m} / \mathrm{z}$ 311.0438, $\mathrm{C}_{13} \mathrm{H}_{11} \mathrm{O}_{9}{ }^{-}$), O-caffeoylquinic acid (peak 32; m/z 353.0911, $\mathrm{C}_{16} \mathrm{H}_{17} \mathrm{O}_{9}{ }^{-}$) and caffeic acid ethyl ester (peak 54; $m / z 207.068, \mathrm{C}_{11} \mathrm{H}_{11} \mathrm{O}_{4}{ }^{-}$). Another caffeoyl moiety was detected in the peak $23[\mathrm{M}-\mathrm{H}]^{-} \mathrm{m} / z$ 341.0912, annotated as $\mathrm{O}$-caffeoylhexose. In the same context, peak 31 demonstrated a molecular ion at $m / z 309.0283\left(\mathrm{C}_{13} \mathrm{H}_{9} \mathrm{O}_{9}{ }^{-}\right)$with a caffeoyl moiety and annotated as caffeoyl-O-dihydroxy maleic acid. Peak 39 displayed a deprotonated molecular ion at $m / z 325.0599$ with an intense product ion at $\mathrm{m} / \mathrm{z} 193$ attributed to feruloyl moiety and identified as feruloyl tartaric acid. Furthermore, peak 37 revealed a molecular ion at $m / z 295.0488\left(\mathrm{C}_{13} \mathrm{H}_{11} \mathrm{O}_{8}{ }^{-}\right)$with $\mathrm{MS}^{2}$ spectrum characterized by a coumaroyl moiety at $m / z 163$ and confirmed its identification as $p$-coumaroyl tartaric acid. Gallic acid and all aforementioned phenolic acid esters are reported for the first time in L. nudicaulis.

Four phenolic compounds are also reported here for the first time in L. nudicaulis, namely hydroxybutylmethoxyphenol, methoxyphenylacetic acid, methylbatatasin III, and phenethylphenol. Peak $53[\mathrm{M}+\mathrm{H}]^{+} \mathrm{m} / z 197.1188$ exhibited product ions at $\mathrm{m} / z 166$ and 123 due to the loss of methoxy and hydroxybutyl moieties, respectively annotated as hydroxybutyl-methoxy-phenol. Likewise, methylbatatasin III (peak 20; m/z 259.1326, $\mathrm{C}_{16} \mathrm{H}_{19} \mathrm{O}_{3}{ }^{+}$) formed product ions at $m / z 123$ and 108, indicating a methoxy-phenol and methoxy-benzene groups, respectively.

\subsubsection{Fatty Acids and Sphingolipids}

Nineteen fatty acids encompassing hydroxylated and polyunsaturated forms represent one of the major classes in L. nudicaulis. Peak $88\left(\mathrm{~m} / z\right.$ 349.2602, $\left.\mathrm{C}_{18} \mathrm{H}_{37} \mathrm{O}_{6}{ }^{+}\right)$annotated as tetrahydroxyoctadecanoic acid was the only saturated fatty acid, suggesting a good effect of L. nudicaulis extract on human lipid profile. Being precursors of prostaglandins, lipoxin (peak 62; $m / z 353.2317, \mathrm{C}_{20} \mathrm{H}_{33} \mathrm{O}_{5}{ }^{+}$), oxolipoxin (peak 66; $m / z 351.2159, \mathrm{C}_{20} \mathrm{H}_{31} \mathrm{O}_{5}{ }^{+}$), linolenic acid (peak 89; $m / z$ 279.2332, $\mathrm{C}_{18} \mathrm{H}_{31} \mathrm{O}_{2}{ }^{+}$) and its methyl ester (peak 98; $m / z$ 293.2487, $\mathrm{C}_{19} \mathrm{H}_{33} \mathrm{O}_{2}{ }^{+}$) exhibited anti-inflammatory effects [56]. Moreover, some hydroxylated fatty acids were present as major peaks and showed additional water molecule loss, aside from their cytotoxic and antimicrobial capacity [57]. For example, hydroxylinolenic acid (293.215, $\left.\mathrm{C}_{18} \mathrm{H}_{29} \mathrm{O}_{3}{ }^{-}\right)$and hydroxyolinoleic acid $\left(295.2303, \mathrm{C}_{18} \mathrm{H}_{31} \mathrm{O}_{3}{ }^{-}\right)$revealed 2 amu mass differences attributed to the extra double bond with fragment ions at $\mathrm{m} / \mathrm{z} 275$ and 277, respectively due to the subsequent loss of one water molecule. Similarly, compound 63 (309.207, $\mathrm{C}_{18} \mathrm{H}_{29} \mathrm{O}_{4}{ }^{+}$) demonstrated the main MS/MS fragment at $m / z 273$ rationalized by the loss of two water molecules and tentatively characterized as hydroxy-oxo-octadecatrienoic acid. Sphingolipids, detected in peaks 106 (570.5157, $\mathrm{C}_{34} \mathrm{H}_{68} \mathrm{NO}_{5}{ }^{-}$) and 108 (682.6342, $\mathrm{C}_{42} \mathrm{H}_{84} \mathrm{NO}_{5}{ }^{+}$), are involved in several cellular responses viz., autophagy and apoptosis [58]. Peak no. 109 at $m / z 842.6782\left(\mathrm{C}_{48} \mathrm{H}_{92} \mathrm{NO}_{10}{ }^{-}\right)$with a characteristic fragment ion at $\mathrm{m} / \mathrm{z}$ 179 indicating a hexose moiety was annotated as iotroridoside. It was previously isolated from a marine sponge Iotrochota ridley with potent anti-cancer activity [59]. Another sphingolipid (peak 76; $\mathrm{m} / \mathrm{z} 318.2982, \mathrm{C}_{18} \mathrm{H}_{40} \mathrm{NO}_{3}{ }^{+}$) composed of a long-chain amino alcohol was identified as aminooctadecanetriol.

\subsubsection{Amino Acids/Peptides}

Being precursors for protein biosynthesis, amino acids and peptides are valuable constituents of food [60]. Acetylated amino acids showed fragment ions attributed to the loss of the acetyl group ( $-42 \mathrm{amu})$, as indicated in peak $45\left(\mathrm{~m} / z 206.0835, \mathrm{C}_{11} \mathrm{H}_{12} \mathrm{NO}_{3}{ }^{-}\right.$) with a product ion at $\mathrm{m} / \mathrm{z} 164$ corresponding to phenylalanine moiety and annotated as $\mathrm{N}$-acetyl-L-phenylalanine. Likewise, peak $13\left(\mathrm{~m} / \mathrm{z} 144.067, \mathrm{C}_{6} \mathrm{H}_{10} \mathrm{NO}_{3}{ }^{-}\right)$displayed a loss of acetyl group $\left.(\mathrm{m} / \mathrm{z} 102 \text { [M-H-acetyl }]^{-}\right)$followed by a consequent loss of amino group $(\mathrm{m} / \mathrm{z}$ 87 [M-H-acetyl-NH] $]^{-}$) and annotated as $\mathrm{N}$-acetylglycine ethyl ester. 


\subsubsection{Organic Acids}

Being eluted earlier due to its high polarity, organic acids of L. nudicaulis included quinic (2) and malic (4) acids. Two related organic acids, peaks 24 and 40, with molecular ions $[\mathrm{M}+\mathrm{H}]^{+} \mathrm{m} / \mathrm{z} 229.1443 \mathrm{C}_{12} \mathrm{H}_{21} \mathrm{O}_{4}{ }^{+}$and $[\mathrm{M}-\mathrm{H}]^{-} \mathrm{m} / \mathrm{z} 225.1157 \mathrm{C}_{12} \mathrm{H}_{17} \mathrm{O}_{4}{ }^{-}$were annotated as hydroxy-dihydrojasmonic and hydroxyjasmonic acids, respectively.

\subsubsection{Nitrogenous Compounds}

Nitrogenous compounds were detected in positive ion mode due to preferential ionization in that mode, and included aminobenzoic acid (5), dimethylamino-benzaldehyde (12), hydroxybenzylamine (9) and phenylethylamine (22).

In the present study, antidiabetic potentiality of L. nudicaulis EtOH extract was evaluated in STZ-induced rats. The hypoglycemic effect of L. nudicaulis represented a significant reduction on blood glucose levels concurrent with a significant induction on blood insulin levels as well as a significant amelioration in weekly body gain of rats compared with glibenclamide as a reference drug. The reduction of the blood glucose levels via the effect of the extract induction might be ascribed to its capacity to increase glucose absorption as well as the decreasing of the glucagon releasing (11). All these effects were documented from several medicinal plants including some Launaea plants such as L. taraxacifolia and $L$. cornuta [61]. Also, the inhibitory action of the extract of $\alpha$-glucosidase might be one of the possible mechanismatic pathways that increase the polysaccharide conversion to simple sugars [62].

Our findings exhibited that the L. nudicaulis extract caused GSH depletion along with potent decreasing of CAT, GR, GST and GPx, as well as significant increasing of MDA content comparing with glibenclamide drug. These results caused decreasing the oxidative stress that manage the diabetic and its associated disorders [3].DM represented dangerous diseases on the liver cells due to the main role of the liver in carbohydrates metabolism. The biochemical analysis exhibited the significant enhancement of all the functions of the liver comparing to the diabetic control group as well as the reference drug, glibenclamide. A significant increasing of total protein, albumin, and globulin as well as decreasing of AST, ALT and ALP were detected by the induction of the two doses of the extract comparing with the negative, glibenclamide and diabetic control groups. Moreover, the L. nudicaulis extract was found to improve the renal functions including that deduced via enhancement of creatinine, uric acid, and urea compared with glibenclamide. All these data are in full agreement with Gbadmosi, et al.'s results [61]. All the results revealed to the capability of the extract to manage the serum insulin levels along with the weekly body weight. Nevertheless, observed increase in rats body weight than the negative control group might refer to a side effect that should be more studied in the future.

This activity was also associated with a safety margin that via a significant enhancement of liver, kidney and testis functions along with antioxidant system. Histopathological studies deduced these findings where L. nudicaulis extract recovered the alternations in pancreas, liver, kidney, and testis that occurred as a response to diabetes induction. Also, our results revealed that, severe disruption of spermatogenesis in the untreated diabetic rats in comparison with the control, glibenclamide and L. nudicaulis treated diabetic rats, as reported in previous studies [63], the cellular levels have been reduced of spermatocytes and spermatids; diabetes has been reported to reduce the number of spermatogenic cells, and the diameter of the seminiferous tubules as a result of oxidative stress and cellular apoptosis [64]. Sertoli cells showed degeneration and necrosis as well as atrophy and vacuolations of Leydig cells because of the alterations in pituitary gonadotropins, depression of synthesis and secretion of testosterone by Leydig cells [65] and the stimulated expression of Caspase12, Grp78, and Chop., inducing cell cycle arrest and apoptosis of Leydig cells [66]. These severe histopathological alterations were, however, ameliorated by extract of $L$. taraxacifolia, this marked improvement is attributed to its flavonoids enriched contents, as previously documented by Adejuwon, et al. [67]. Moreover, Khan [68] suggested that $L$. procumbens extract has a great capability to protect testis against testicular 
oxidative damages, possibly credited to its antioxidant effects of its bioactive compounds. The improvement in the histopathological picture noticed in all examined sections from L. nudicaulis groups which is attributed to lowering of the elevated blood glucose levels [69], the significant hypoglycemic effect that agreed with the present findings that treated diabetic rats with $L$. nudicaulis and reduced histopathological alterations due to the antioxidant nature as well as decreasing of apoptosis $\beta$-cells and oxidative stress reduction [70]. The islet cell injury, particularly $\beta$-cell damage is attributed to the increased oxidative stress, metabolic stress, increased endoplasmic reticulum stress, activation of inflammatory pathways, and the hyperglycemia; hyperlipidemia causing cellular apoptosis [71,72]. Glibenclamide- and L. nudicaulis-treated diabetic rats showed an improvement in the islet cell morphology with still minimal apoptotic changes and reduction in the size and number of the islets of Langerhans. These findings were consistent with the results of Erejuwa, et al. [73] who showed that glibenclamide preserved beta-cell mass and morphology in diabetic rats. Khan, et al. [74] found that L. procumbens protected the antioxidant machineries of the pancreas, due to phenolic and polyphenolic compounds as well as its marked protection against DNA damage. All these results revealed a potent hypoglycemic effect with a reasonable margin of safety, qualifying it as a drug for controlling diabetes.

The biological potentialities of the medicinal plants are directly correlated with their secondary metabolites. According to this fact, the significant role of L. nudicaulis ethanolic extract on diabetes mellitus and its comorbidities in diabetic control rats was established upon the metabolites of the plant. The chemical profile revealed that is rich with several metabolite classes including flavonoids, phenolics, fatty acids, sphingolipids, amino acids, peptides, organic acids, and nitrogenous compounds. All these classes of metabolites were already described to exert biological activities against hepatic damage and toxicity $[19,75]$, hyperlipidemia [76], diabetes [19], and gastric ulcers [8,77].

The polyphenolics in L. nudicaulis including phenolic acids and flavonoids, were reported to have potential role in the inhibition and/or controlling of diabetes via several pathways such as (i) pancreatic islet $\beta$-cell protection, (ii) inhibition and/or decrease of $\beta$ cell apoptosis, (iii) increased $\beta$-cell proliferation, (iv) oxidative stress reduction, (v) insulin secretion activation, (vi) digestive enzymes and glucose absorption inhibition, and other effects [70]. Additionally, the roles of these phenolic compounds in the enhancement of diabetic complications were reported [61] and help account for the protective effects observed in this study. The simple phenolic acids i.e., gallic, caffeic, and $p$-coumaric acids and their derivatives were described as significant hypoglycemic agents [78,79], which act through multiple mechanisms i.e., inhibition of gluconeogenesis, increasing of C-peptide and insulin secretion and glycolysis, enhancing of the functions of liver and renal in addition of others [70].

Likewise, flavonoids have been described as potential hypoglycemic agents that may act via several mechanisms including: (i) enhancement of activated cellular protein expression of the adenosine monophosphate-activated protein (AMP), (ii) reduction of the apoptosis of the cellular via caspase 3 deactivation, (iii) activation of the insulin secretion and production from $\beta$-cells, (iv) increasing of cells absorption of the glucose, and (v) activation of the new glucose carriers synthesis $[70,80,81]$.

Nobiletin, a hexamethoxyflavone, demonstrated antidiabetic and anti-inflammatory activities [82]. Moreover, tangeretin, a pentamethoxyflavone, improves secretion of insulin and decreases blood glucose via stimulating glucose uptake [83]. Compared to phenolic acids and flavonoids, relatively polar metabolites, non-polar constituents such as sphingolipids also detected in this study are recorded as potential antidiabetic agents [84]. Sphingolipids acted via numerous pathways comprising the inauguration of apoptosis of $\beta$-cell, insulin resistance, and decreasing of the insulin gene expression [84].

The chemical profiling suggests that as typical in most plant extracts, antidiabetic action in L. nudicalis is more likely mediated via a synergized action of metabolites for enhancement of antidiabetic activity of L. nudicalis. 


\section{Materials and Methods}

\subsection{Plant Materials Collection, Identification, and Extract Preparation}

The aerial parts of L. nudicaulis were collected from Wadi Hagul, Eastern Desert of Egypt $\left(30^{\circ} 02^{\prime} 34.3^{\prime \prime} \mathrm{N} 32^{\circ} 05^{\prime} 40.6^{\prime \prime} \mathrm{E}\right)$, during the flowering stage in April 2018. The identification of the plant was performed by Dr. Ahmed M. Abd-ElGawad, Associate professor of plant ecology, Faculty of Science, Mansoura University, Mansoura, Egypt, according to Boulos [85] and Tackholm [86]. A plant voucher specimen (Mans.001121406) was deposited in the herbarium of Botany Department, Faculty of Science, Mansoura University, Mansoura, Egypt.

The collected plant materials were dried in air and shade condition for ten days. After complete dryness, the sample $(760 \mathrm{~g})$ was ground into a fine powder, extracted with a mixture of $\mathrm{H}_{2} \mathrm{O}-\mathrm{EtOH}(3: 7,3 \mathrm{~L})$ at room temperature $\left(25 \pm 2{ }^{\circ} \mathrm{C}\right)$, and then filtered. The extraction procedure was performed three times. All the extracts were collected and dried under reduced pressure to afford black gum $(28.7 \mathrm{~g})$. The extract was stored at $4{ }^{\circ} \mathrm{C}$ in the deep freezer until further chemical and biological analyses.

\subsection{Chemicals}

Streptozotocin were purchased from Sigma-Aldrich Company (St. Louis, MO, USA). the diabetic drug glibenclamide (Daonil ${ }^{\circledR}$ ) was obtained from Sanofi Aventis (Cairo, Egypt). All kits were obtained from Biodigonestic Diagnostics Egypt (Dokki, Giza, Egypt). All used chemicals were analytical grade. Ethanol (99\%) was purchased from El-Naser Company for Intermediate Chemicals (Cairo, Egypt).

\subsection{Experimental Animals}

Healthy adult male albino rats of Wistar strain (160-200 g weight 60-80 day age), were obtained from the central animal house of National Research Centre (Dokki, Giza, Egypt). The central animal house conditions were well ventilated, 20 to $25^{\circ} \mathrm{C}$ temperature, $50-55 \%$ of relative humidity and $12 \mathrm{~h}$ dark/light cycle. Rats were kept in plastic hygienic cages during the experimental period ( 6 weeks). Pellet diet was obtained from the central animal house of National Research Centre. The diet contains $4.60 \%$ fat, $25.00 \%$ crude protein, $4.78 \%$ crude fiber and $6.71 \%$ crude ash (the diet composition was analyzed according to AOAC [87]. Pellets and water were ad libitum. The study was conducted based upon the rules of the ethics committee of the National Research Centre and in accordance with the Guide for the Care and Use of Laboratory Animals of the National Institutes of Health in compliance with the guidelines from the Canadian Council on Animal Care (approval no: 19-074).

\subsection{Acute Toxicity $\left(L D_{50}\right)$}

Acute toxicity of the EtOH extract of L. nudicaulis was performed according to per OECD guideline 4235 [88] (2001). Dosing pattern started from $1 \mathrm{~g} / \mathrm{kg}$ as a single dose and increased to reach $6 \mathrm{~g} / \mathrm{kg}$ body weight orally, while the control group received only normal saline. Mortality in all groups ( 8 mice each) was observed for $48 \mathrm{~h}$ for assessing toxicity. Alive animals were observed for a period of two weeks. Using mortality number in each concentration during the first $48 \mathrm{~h}$ and BioStat program (BioStat 2009 Build 5.8.4.3 202021 analystSoft Inc., Alexandria, VA, USA), the extract dose that killed 50\% of the animals $\left(\mathrm{LD}_{50}\right)$ was estimated at $5 \mathrm{~g} / \mathrm{kg}$.

\subsection{Hypoglycemic Experiment}

\subsubsection{Diabetes Induction}

Wistar-albino male rats (160-200 g) were intraperitoneally i.p. injected with one dose of streptozotocin (STZ). Overnight fasted rats were injected with freshly STZ in $0.1 \mathrm{M}$ citrate buffer ( $\mathrm{pH} 4.5)$ at a dose of $55 \mathrm{mg} / \mathrm{kg}$. STZ- injected rats were administrated glucose $(25 \%)$ after one hour of STZ injection, and they were kept on glucose $(5 \%)$ overnight to overcome STZ-induced hyperglycemia [89]. Diabetes was presented by the presence 
of hyperglycemia, polyuria, and body weight loss. After seven days from STZ-injection, fasting blood glucose levels were measured for all STZ animals. Animals with blood glucose levels above $250 \mathrm{mg} / \mathrm{dL}$, were considered as diabetic and were selected for subsequent experiments [4].

\subsubsection{The L. nudicaulis Extract and Standard Drug Dosing Protocol}

According to Ghosh [90] and Garg, et al. [91], two doses of 500 and $250 \mathrm{mg} / \mathrm{kg}$ body weight were selected to assess the anti-hyperglycemic effect of the ethanolic extract of $L$. nudicaulis at 10th and 20th of the $\mathrm{LD}_{50}$ value. The anti-hyperglycemic effect was evaluated by comparing it with the effect of the standard drug glibenclamide. The glibenclamide was tested at its recommended dose of $5 \mathrm{mg} / \mathrm{kg} /$ day [92]. Animals administered both extract and glibenclamide dissolved in $1.0 \mathrm{~mL}$ normal saline $(0.9 \%)$ orally using a stomach tube.

\subsubsection{Experimental Design}

Seventy male rats were divided into two main groups. 1st group was non-diabetic rats (ten rats), were injected with $1.00 \mathrm{~mL}$ of $0.1 \mathrm{M}$ citrate buffer ( $\mathrm{pH} 4.5$ ) only and served as a negative control for five weeks. The 2 nd group was the diabetic group (60 rats), rats were injected with a single dose of STZ at $55 \mathrm{mg} / \mathrm{kg}$ in citrate buffer, and after one week, fasting blood glucose levels were measured for all animals in this group, and animals with the highest blood glucose (above $250 \mathrm{mg} / \mathrm{dL}$ ) levels were selected for subsequent experiments (44 rats). Then, the 2nd group, Forty- four diabetic male albino rats, was divided into four subgroups: Subgroup I: diabetic rats (14 rats) administrated saline for five weeks, and was kept as diabetic control. Subgroup II: diabetic rats (10 rats), administrated ethanolic extract of L. nudicaulis at $250 \mathrm{mg} / \mathrm{kg}$ body weight/day for five weeks. Subgroup III: diabetic rats (10 rats), administrated with ethanolic extract of L. nudicaulis at $500 \mathrm{mg} / \mathrm{kg}$ body weight/day for five weeks. Subgroup IV: diabetic rats (10 rats), administrated with glibenclamide at a recommended dose of $5 \mathrm{mg} / \mathrm{kg}$ body weight/day for five weeks.

Using a digital balance, rats were weighed at the start of the experiment, and every week for five weeks. After five weeks (experimental period), rats were anesthetized by injection of $87 \mathrm{mg} / \mathrm{kg}$ of body weight and xylazine $13 \mathrm{mg} / \mathrm{kg}$ dissolved in normal saline and each rat i.p. simultaneous received $0.2 \mathrm{~mL} / 100 \mathrm{~g}$ body weight [93]. Under anesthesia, blood samples were collected from the retro-orbital plexus using capillary tube. Sera were separated by centrifugation ( $4000 \times g$ and 10 min using a Sigma Labor Zentrifugen). Organs were collected, washed with ice saline solution, and then weighted freshly. A piece of pancreas, liver, kidney, and testis from each rat was kept immediately in formalin $10 \%$ for histopathological examination.

\subsubsection{Measurement of Blood Glucose Levels}

Every week during the experimental period, rats fasted overnight, and blood samples were collected from the tip of tail veins of each rat. The blood sample were collected in the morning (at 9 o'clock) prior to administering the extract or eating food to determine the fasting blood glucose level. Based on the glucose oxidase method, glucose concentration was estimated in whole blood samples immediately after collection, using Gluco Star Test Strip (Taidoc Technology Corp., New Taipei, Taiwan). The change percentage in each row calculated as:

Change $\%=[($ concentration at start time- concentration at 1 st week $) /$ concentration at start time $] \times 100$

\subsubsection{Determination of Serum Insulin Level and Serum Lipid Profile}

Serum insulin level was measured using rat insulin ELISA kits from BioVision Incorporated (Milpitas, CA, USA). Lipid profile including; total cholesterol (TC), high-density lipoprotein cholesterol (HDL-C), and triglycerides (TG) were estimated according to Allain, et al. [94], Naito [95], and Fossati and Prencipe [96], respectively. Low-density lipoprotein cholesterol (LDL-C), very low-density lipoprotein cholesterol (VLDL-C), and 
risk ratio were calculated according to Naito [95], Friedewald, et al. [97], and KikuchiHayakawa, et al. [98], respectively.

\subsubsection{Determination of Liver and Kidney Functions}

Liver function parameters; total protein, albumin and liver enzymes activities; alkaline phosphatase (ALP), aspartate aminotransferase (AST) and alanine aminotransferase (ALT), were measured spectrophotometrically according to Henry [99], Doumas, et al. [100], Belfield and Goldberg [101], and Rettman and Frankel [102], respectively. Globulin was calculated by the difference between total protein and albumin [103]. Kidney function parameters; urea, uric acid, and creatinine, were estimated spectrophotometrically as methods described by Tabacco, et al. [104], Gochman and Schmitz [105], and Faulkner and King [106], respectively.

\subsubsection{Determination of Antioxidant and Oxidative Stress Biomarkers of Serum}

The malondialdehyde (MDA) was usually used as oxidative stress parameters. The MDA was determined spectrophotometrically following the method of Ohkawa, et al. [107]. Non enzymatic antioxidant, reduced glutathione concentration (GSH) was determined in serum according to the method of Griffith [108]. Enzymatic antioxidants parameters including glutathione reductase (GR), Glutathione-S-transferase (GST), Glutathione peroxidase (GPx), and catalase (CAT) activities were determined spectrophotometrically in serum according to Goldberg and Spooner [109], Paglia and Valentine [110], Habig, et al. [111], and Beers and Sizer [112], respectively.

\subsection{Histopathological Examination}

The testis, pancreas, kidney and liver specimens were instantly dissected out, excised, and fixed in $10 \%$ neutral buffered formalin fixative solution, dehydrated and embedded in paraffin; solid sections of $4-5 \mu \mathrm{m}$. The sections were stained with hematoxylin-eosin ( $\mathrm{H} \& \mathrm{E}$ ) and followed by investigation using a light microscope (CX 41, Olympus, Tokyo, Japan) [113].

\subsection{High-Resolution Ultra-Performance Liquid Chromatography-Mass Spectrometry Analysis} (UPLC-ESI-qTOF-MS)

UPLC-MS analysis was performed following exact conditions described in Farrag, et al. [8]. Briefly, dried finely pulverized L. nudicaulis specimen $(10 \mathrm{mg})$ was extracted by adding $2 \mathrm{~mL} 100 \% \mathrm{MeOH}$, containing $10 \mu \mathrm{g} / \mathrm{mL}^{-1}$ umbelliferone as an internal standard sonicated for $20 \mathrm{~min}$ with frequent shaking, then centrifuged at $12,000 \times g$ for $10 \mathrm{~min}$ to remove debris. The filtered extract through a $22-\mu \mathrm{m}$ filter (about $500 \mu \mathrm{L}$ ) was subjected to solid-phase extraction using a $\mathrm{C}_{18}$ cartridge as previously described [114]. L. nudicaulis extract $(2 \mu \mathrm{L})$ was loaded on HSS T3 column $(100 \times 1.0 \mathrm{~mm}$, particle size $1.8 \mu \mathrm{m}$; Waters) installed on an ACQUITY UPLC system (Waters, Milford, MA, USA) equipped with a 6540 Ultra-High-Definition (UHD) Accurate-Mass Q-TOFLC/MS (Agilent, Palo Alto, CA, USA) coupled to an ESI interface, operated in positive or negative ion mode following conditions described in 113. Characterization of compounds was performed by the generation of the candidate formula with a mass accuracy limit of $10 \mathrm{ppm}$, and also considering RT, tandem MS2 data, and searching reference literature and the Phytochemical Dictionary of Natural Products Database. Peaks were detected in both negative and positive (deviating values in brackets) ion modes.

\subsection{Statistical Analysis}

Data were expressed as mean \pm SE (standard error) for 10 rats. Variables of blood glucose concentration and body weight were statistically analyzed by two-way ANOVA followed by a Duncan's hoc test, was used to compare multiple groups, and all comparisons were significant when $p \leq 0.05$ using software COSTAT (version 6.400, Cohort Software, Birmingham, UK). Other results were statistically analyzed by one-way ANOVA followed 
by a by a Duncan's hoc test, was used to compare multiple groups, and all comparisons were significant when $p \leq 0.05$ using software COSTAT.

\section{Conclusions}

Our study provides the first insights into the antidiabetic potential of L. nudicaulis alcoholic extract in STZ-induced diabetic rats as revealed via biochemical and histopathological examinations. The extract reduced blood glucose levels and increased the serum insulin levels of diabetic control rats. Additionally, the extract prevented diabetic complications, including loss of weight, liver and kidney disruption and oxidative stress. Whether the anti-diabetic effect of L. nudicaulis ehtanolic extract is attributable to the action of a single chemical or the synergy of multi-components as typical in phytomedicines has yet to be confirmed using isolated compound bioassays. The myriad of chemical classes identified in extract including flavonoids, phenolics, acyl glycerols and nitrogenous compounds, several of which are reported antidiabetic agents suggests more for a synergized action and should be the next logical step. Fractionation and or isolation of the crude extract should help confirm such hypothesis.

Supplementary Materials: The following are available online. Table S1: Toxicological study of different doses of $L$. nudicaulis ethanolic extract administered orally in mice.

Author Contributions: Conceptualization, S.A.E.-N., S.M.A., M.S.A., R.F.A., A.E.-N.G.E.G., A.M.A.E., M.A.F. and A.I.E.; Formal analysis, S.A.E.-N., S.M.A., M.S.A., R.F.A., A.E.-N.G.E.G., M.A.F. and A.I.E.; Investigation, S.A.E.-N., S.M.A., M.S.A., R.F.A., A.E.-N.G.E.G., A.M.A.-E., M.A.F., A.M.E. and A.I.E.; Writing—original draft, S.A.E.-N., A.M.A.-E., M.A.F. and A.I.E.; Writing-review \& editing, S.A.E.-N., S.M.A., M.S.A., R.F.A., A.E.-N.G.E.G., A.M.A.-E., M.A.F., A.M.E. and A.I.E. All authors have read and agreed to the published version of the manuscript.

Funding: This research received no external funding.

Institutional Review Board Statement: The study was conducted based upon the rules of the ethics committee of the National Research Centre and in accordance with the Guide for the Care and Use of Laboratory Animals of the National Institutes of Health in compliance with the guidelines from the Canadian Council on Animal Care (approval no: 19-074).

Acknowledgments: The authors gratefully acknowledge the National Research Centre, Cairo, Egypt for the support.

Conflicts of Interest: The authors declare no conflict of interest.

Sample Availability: Samples of the compounds are not available from the authors.

\section{References}

1. Saeedi, P.; Petersohn, I.; Salpea, P.; Malanda, B.; Karuranga, S.; Unwin, N.; Colagiuri, S.; Guariguata, L.; Motala, A.A.; Ogurtsova, K. Global and regional diabetes prevalence estimates for 2019 and projections for 2030 and 2045: Results from the International Diabetes Federation Diabetes Atlas. Diabetes Res. Clin. Pract. 2019, 157, 107843. [CrossRef]

2. Thomas, R.; Halim, S.; Gurudas, S.; Sivaprasad, S.; Owens, D. IDF Diabetes Atlas: A review of studies utilising retinal photography on the global prevalence of diabetes related retinopathy between 2015 and 2018. Diabetes Res. Clin. Pract. 2019, 157, 107840. [CrossRef]

3. Osawa, T.; Kato, Y. Protective role of antioxidative food factors in oxidative stress caused by hyperglycemia. Ann. N. Y. Acad. Sci. 2005, 1043, 440-451. [CrossRef]

4. Yin, P.; Zhao, S.; Chen, S.; Liu, J.; Shi, L.; Wang, X.; Liu, Y.; Ma, C. Hypoglycemic and hypolipidemic effects of polyphenols from burs of Castanea mollissima Blume. Molecules 2011, 16, 9764-9774. [CrossRef] [PubMed]

5. Abdel-Haleem, S.A.; Ibrahim, A.Y.; Ismail, R.F.; Shaffie, N.M.; Hendawy, S.; Omer, E. In-vivo hypoglycemic and hypolipidemic properties of Tagetes lucida alcoholic extract in streptozotocin-induced hyperglycemic Wistar albino rats. Ann. Agric. Sci. 2017, 62, 169-181. [CrossRef]

6. Ricci, G.; Catizone, A.; Esposito, R.; Pisanti, F.; Vietri, M.T.; Galdieri, M. Diabetic rat testes: Morphological and functional alterations. Andrologia 2009, 41, 361-368. [CrossRef] [PubMed]

7. Shojaei Andebili, S.; Dehghani Firoozabadi, A.; Behnam Rassouli, M.; Mahdavi SHahri, N.; Haghparast, A. Morphological evaluation of testis tissue of rats in various time points after diabetes type 1 induction. Iran. J. Diabetes Obes. 2014, 5, 98-106. 
8. Farrag, A.R.H.; Abdallah, H.M.; Khattab, A.R.; Elshamy, A.I.; El Gendy, A.E.-N.G.; Mohamed, T.A.; Farag, M.A.; Efferth, T.; Hegazy, M.-E.F. Antiulcer activity of Cyperus alternifolius in relation to its UPLC-MS metabolite fingerprint: A mechanistic study. Phytomedicine 2019, 62, 152970. [CrossRef] [PubMed]

9. Al-Mahrezi, J.A.; Al-Sabahi, J.N.; Akhtar, M.S.; Selim, D.; Weli, A.M.; JIJoPS, R. Essential oil composition and antimicrobial screening of Launaea nudicaulis grown in Oman. Int. J. Pharm. Sci. Res. 2011, 2, 3166-3169.

10. Elshamy, A.I.; Abd-ElGawad, A.M.; El-Amier, Y.A.; El Gendy, A.E.N.G.; Al-Rowaily, S.L. Interspecific variation, antioxidant and allelopathic activity of the essential oil from three Launaea species growing naturally in heterogeneous habitats in Egypt. Flavour Fragr. J. 2019, 34, 316-328. [CrossRef]

11. Cole, M. Key antifungal, antibacterial and anti-insect assays-A critical review. Biochem. Syst. Ecol. 1994, 22, 837-856. [CrossRef]

12. El-Sharkawy, E.R.; Ed-Dra, A.; Abdallah, E.M. Phytochemical, antimicrobial and antioxidant properties of Launaea nudicaulis and Farsetia hamiltonii. J. Biol. Control 2017, 31, 102-109. [CrossRef]

13. Saleem, M.; Parveen, S.; Riaz, N.; Tahir, M.N.; Ashraf, M.; Afzal, I.; Ali, M.S.; Malik, A.; Jabbar, A. New bioactive natural products from Launaea nudicaulis. Phytochem. Lett. 2012, 5, 793-799. [CrossRef]

14. Chauhan, A.; Sharma, P.; Srivastava, P.; Kumar, N.; Dudhe, R. Plants having potential antidiabetic activity: A review. Der Pharm. Lett. 2010, 2, 369-387.

15. Cheriti, A.; Belboukhari, M.; Belboukhari, N.; Djeradi, H. Phytochemical and biological studies on Launaea Cass. genus (Asteraceae) from Algerian Sahara. Phytochemistry 2012, 11, 67-80.

16. Sepehri-Moghadam, H.; Rahbarian, R.; Sadoughi, S.D. The effect of aqueous extract of Launaea acanthodes (Boiss.) O. Kuntze on the serum level of insulin and blood glucose and histomorphological changes of pancreas in diabetic rats. Feyz J. Kashan Univ. Med. Sci. 2015, 19, 30-37.

17. Adinortey, M.B.; Sarfo, J.K.; Kwarteng, J.; Adinortey, C.A.; Ekloh, W.; Kuatsienu, L.E.; Kwadwo Nyarko, A. The ethnopharmacological and nutraceutical relevance of Launaea taraxacifolia (Willd.) Amin ex C. Jeffrey. Evid.-Based Complementary Altern. Med. 2018, 2018, 7259146. [CrossRef]

18. Abdallah, H.M.I.; Elshamy, A.I.; El Gendy, A.E.-N.G.; Abd El-Gawad, A.M.; Omer, E.A.; De Leo, M.; Pistelli, L. Anti-inflammatory, antipyretic, and antinociceptive effects of a Cressa cretica aqueous extract. Planta Med. 2017, 83, 1313-1320. [CrossRef] [PubMed]

19. El-Newary, S.A.; Shaffie, N.M.; Omer, E. The protection of Thymus vulgaris leaves alcoholic extract against hepatotoxicity of alcohol in rats. Asian Pac. J. Trop. Med. 2017, 10, 361-371. [CrossRef] [PubMed]

20. Mohsen-Nia, M.; Amiri, H. Measurement and modelling of static dielectric constants of aqueous solutions of methanol, ethanol and acetic acid at $\mathrm{T}=293.15 \mathrm{~K}$ and $91.3 \mathrm{kPa}$. J. Chem. Thermodyn. 2013, 57, 67-70. [CrossRef]

21. Miguel, M.G.; Nunes, S.; Dandlen, S.A.; Cavaco, A.M.; Antunes, M.D. Phenols and antioxidant activity of hydro-alcoholic extracts of propolis from Algarve, South of Portugal. Food Chem. Toxicol. 2010, 48, 3418-3423. [CrossRef] [PubMed]

22. Sahu, N.; Singh, A.; Khatoon, S.; Kumar, B.; Arya, K. Macro-microscopic and LCMS markers for identification and authentication of herbal formulations of Taraxacum officinale and Launaea procumbens. Int. J. Res. Pharm. Sci. 2017, 8, 301-310.

23. Dhananjeyan, M.R.; Bykowski, C.; Trendel, J.A.; Sarver, J.G.; Ando, H.; Erhardt, P.W. Simultaneous determination of procaine and para-aminobenzoic acid by LC-MS/MS method. J. Chromatogr. B 2007, 847, 224-230. [CrossRef] [PubMed]

24. Fernández-Fernández, R.; López-Martínez, J.C.; Romero-González, R.; Martínez-Vidal, J.L.; Flores, M.I.A.; Frenich, A.G. Simple LC-MS determination of citric and malic acids in fruits and vegetables. Chromatographia 2010, 72, 55-62. [CrossRef]

25. Rhouati, S.; Ahmed, A.A.; Ouahrani, M.R. Isolation of coumarins and coumarin glucoside from Launaea resedifolia. Asian J. Chem. 2006, 18, 2348-2352.

26. Pramai, P.; Thongsook, T.; Thanasukarn, P.; Jannoey, P.; Nuengchamnong, N.; Chen, F.; Maulidiani, M.; Abas, F.; Jiamyungyuen, S. Chemical profiles of three varieties of germinated rice based on LC-MS and their antioxidant activity. Food Appl. Biosci. J. 2019, 7, 11-32.

27. Jun, M.; Shao, Y.; Ho, C.-T.; Koetter, U.; Lech, S. Structural identification of nonvolatile dimerization products of glucosamine by gas chromatography - mass spectrometry, liquid chromatography- mass spectrometry, and nuclear magnetic resonance analysis. J. Agric. Food Chem. 2003, 51, 6340-6346. [CrossRef]

28. Xiao, B.; Dong, J.; Yan, M.; Liu, Y.; Li, Y.; Yang, G.; Sun, Z. Development of a liquid chromatography-tandem mass spectrometry method for simultaneous determination of five isoflavonoids and seven neurochemicals in rat brain dialysate and its application to a pharmacological study. J. Sep. Sci. 2018, 41, 2321-2330. [CrossRef]

29. Odukoya, J.; Oshodi, A. Evaluation of the nutritional qualities of the leaves of Parquetina nigrescens, Launaea taraxacifolia and Solanum nigrum. Eur. J. Pure Appl. Chem. 2018, 5, 18-31.

30. Gao, J.; Leung, K.S.; Wang, Y.; Lai, C.; Li, S.; Hu, L.; Lu, G.; Jiang, Z.; Yu, Z. Qualitative and quantitative analyses of nucleosides and nucleobases in Ganoderma spp. by HPLC-DAD-MS. J. Pharm. Biomed. Anal. 2007, 44, 807-811. [CrossRef] [PubMed]

31. Singh, D.; Kumar, S.; Pandey, R.; Hasanain, M.; Sarkar, J.; Kumar, B. Bioguided chemical characterization of the antiproliferative fraction of edible pseudo bulbs of Malaxis acuminata D. Don by HPLC-ESI-QTOF-MS. Med. Chem. Res. 2017, 26, 3307-3314. [CrossRef]

32. Yamaoka, N.; Kaneko, K.; Kudo, Y.; Aoki, M.; Yasuda, M.; Mawatari, K.; Nakagomi, K.; Yamada, Y.; Yamamoto, T. Analysis of purine in purine-rich cauliflower. Nucleosides Nucleotides Nucleic Acids 2010, 29, 518-521. [CrossRef] [PubMed]

33. Lin, L.-Z.; Harnly, J.M. Identification of the phenolic components of chrysanthemum flower (Chrysanthemum morifolium Ramat). Food Chem. 2010, 120, 319-326. [CrossRef] 
34. $\quad$ t'Kindt, R.; De Veylder, L.; Storme, M.; Deforce, D.; Van Bocxlaer, J. LC-MS metabolic profiling of Arabidopsis thaliana plant leaves and cell cultures: Optimization of pre-LC-MS procedure parameters. J. Chromatogr. B 2008, 871, 37-43. [CrossRef]

35. Ostrowski, W.; Wojakowska, A.; Grajzer, M.; Stobiecki, M. Mass spectrometric behavior of phenolic acids standards and their analysis in the plant samples with LC/ESI/MS system. J. Chromatogr. B 2014, 967, 21-27. [CrossRef]

36. Toffali, K.; Zamboni, A.; Anesi, A.; Stocchero, M.; Pezzotti, M.; Levi, M.; Guzzo, F. Novel aspects of grape berry ripening and post-harvest withering revealed by untargeted LC-ESI-MS metabolomics analysis. Metabolomics 2011, 7, 424-436. [CrossRef]

37. Khan, R.A.; Khan, M.R.; Sahreen, S.; Ahmed, M. Assessment of flavonoids contents and in vitro antioxidant activity of Launaea procumbens. Chem. Cent. J. 2012, 6, 1-11. [CrossRef]

38. Cantos, E.; Espin, J.C.; Tomás-Barberán, F.A. Varietal differences among the polyphenol profiles of seven table grape cultivars studied by LC-DAD-MS-MS. J. Agric. Food Chem. 2002, 50, 5691-5696. [CrossRef]

39. Ferrare, K.; Bidel, L.P.; Awwad, A.; Poucheret, P.; Cazals, G.; Lazennec, F.; Azay-Milhau, J.; Tournier, M.; Lajoix, A.-D.; Tousch, D. Increase in insulin sensitivity by the association of chicoric acid and chlorogenic acid contained in a natural chicoric acid extract (NCRAE) of chicory (Cichorium intybus L.) for an antidiabetic effect. J. Ethnopharmacol. 2018, 215, 241-248. [CrossRef]

40. Asif, M.; Saadullah, M.; Yaseen, H.S.; Saleem, M.; Yousaf, H.M.; Khan, I.U.; Yaseen, M.; Shams, M.U. Evaluation of in vivo antiinflammatory and anti-angiogenic attributes of methanolic extract of Launaea spinosa. Inflammopharmacology 2020, 28, 993-1008. [CrossRef]

41. Liu, X.; Yang, Q.; Lu, Y.; Li, Y.; Li, T.; Zhou, B.; Qiao, L. Effect of purslane (Portulaca oleracea L.) extract on anti-browning of fresh-cut potato slices during storage. Food Chem. 2019, 283, 445-453. [CrossRef]

42. Kikowska, M.; Kruszka, D.; Derda, M.; Hadaś, E.; Thiem, B. Phytochemical screening and acanthamoebic activity of shoots from in vitro cultures and in vivo plants of Eryngium alpinum L.-The endangered and protected species. Molecules 2020, $25,1416$. [CrossRef] [PubMed]

43. Ma, X.-Q.; Leung, A.K.M.; Chan, C.L.; Su, T.; Li, W.-D.; Li, S.-M.; Fong, D.W.F.; Yu, Z.-L. UHPLC UHD Q-TOF MS/MS analysis of the impact of sulfur fumigation on the chemical profile of Codonopsis Radix (Dangshen). Analyst 2014, 139, 505-516. [CrossRef] [PubMed]

44. Clifford, M.N.; Knight, S.; Kuhnert, N. Discriminating between the six isomers of dicaffeoylquinic acid by LC-MS n. J. Agric. Food Chem. 2005, 53, 3821-3832. [CrossRef]

45. Mishra, G.J.; Reddy, M.; Rana, J.S. Isolation of flavonoid constituent from Launaea procumbens Roxb. by preparative HPTLC method. IOSR J. Pharm 2012, 2, 5-11. [CrossRef]

46. Moussaoui, F.; Zellagui, A.; Segueni, N.; Touil, A.; Rhouati, S. Flavonoid constituents from Algerian Launaea resedifolia (OK) and their antimicrobial activity. Rec. Nat. Prod. 2010, 4, 91-95.

47. Bastos, K.X.; Dias, C.N.; Nascimento, Y.M.; Da Silva, M.S.; Langassner, S.M.Z.; Wessjohann, L.A.; Tavares, J.F. Identification of phenolic compounds from Hancornia speciosa (Apocynaceae) leaves by uhplc orbitrap-hrms. Molecules 2017, 22, 143. [CrossRef] [PubMed]

48. Farag, M.A.; El-Ahmady, S.H.; Elian, F.S.; Wessjohann, L.A. Metabolomics driven analysis of artichoke leaf and its commercial products via UHPLC-q-TOF-MS and chemometrics. Phytochemistry 2013, 95, 177-187. [CrossRef]

49. Fuchs, D.; Hamberg, M.; Sköld, C.M.; Wheelock, Å.M.; Wheelock, C.E. An LC-MS/MS workflow to characterize 16 regio-and stereoisomeric trihydroxyoctadecenoic acids. J. Lipid Res. 2018, 59, 2025-2033. [CrossRef]

50. Dugo, P.; Mondello, L.; Dugo, L.; Stancanelli, R.; Dugo, G. LC-MS for the identification of oxygen heterocyclic compounds in citrus essential oils. J. Pharm. Biomed. Anal. 2000, 24, 147-154. [CrossRef]

51. Farag, M.A.; Shakour, Z.T.A. Metabolomics driven analysis of 11 Portulaca leaf taxa as analysed via UPLC-ESI-MS/MS and chemometrics. Phytochemistry 2019, 161, 117-129. [CrossRef]

52. Khaled, S.E.; Hashem, F.A.-M.; Shabana, M.H.; Hammam, A.-M.M.; Madboli, A.N.A.; Al-Mahdy, D.A.; Farag, M.A. A biochemometric approach for the assessment of Phyllanthus emblica female fertility effects as determined via UPLC-ESI-qTOF-MS and GC-MS. Food Funct. 2019, 10, 4620-4635. [CrossRef]

53. Riaz, N.; Parveen, S.; Saleem, M.; Ali, M.S.; Malik, A.; Ashraf, M.; Afzal, I.; Jabbar, A. Lipoxygenase inhibitory sphingolipids from Launaea nudicaulis. J. Asian Nat. Prod. Res. 2012, 14, 545-554. [CrossRef] [PubMed]

54. Feng, Y.; Davis, R.A.; Sykes, M.L.; Avery, V.M.; Quinn, R.J. Iotrochamides A and B, antitrypanosomal compounds from the Australian marine sponge Iotrochota sp. Bioorganic Med. Chem. Lett. 2012, 22, 4873-4876. [CrossRef]

55. Panche, A.; Diwan, A.; Chandra, S. Flavonoids: An overview. J. Nutr. Sci. 2016, 5, e47. [CrossRef] [PubMed]

56. Kumar, R.; Clerc, A.-C.; Gori, I.; Russell, R.; Pellegrini, C.; Govender, L.; Wyss, J.-C.; Golshayan, D.; Canny, G.O. Lipoxin A 4 prevents the progression of de novo and established endometriosis in a mouse model by attenuating prostaglandin $\mathrm{E} 2$ production and estrogen signaling. PLoS ONE 2014, 9, e89742. [CrossRef] [PubMed]

57. Snoch, W.; Stępień, K.; Prajsnar, J.; Staroń, J.; Szaleniec, M.; Guzik, M. Influence of chemical modifications of polyhydroxyalkanoatederived fatty acids on their antimicrobial properties. Catalysts 2019, 9, 510. [CrossRef]

58. Mullen, T.; Obeid, L.M. Ceramide and apoptosis: Exploring the enigmatic connections between sphingolipid metabolism and programmed cell death. Anticancer Agents Med. Chem. 2012, 12, 340-363. [CrossRef] [PubMed]

59. Zhang, W.; Guo, Y.-W.; Gu, Y. Secondary metabolites from the South China Sea invertebrates: Chemistry and biological activity. Curr. Med. Chem. 2006, 13, 2041-2090. [CrossRef] 
60. Belitz, H.-D.; Grosch, W.; Schieberle, P. Amino Acids, Peptides, Proteins. In Food Chemistry; Springer: Berlin/Heidelberg, Germany, 2004; pp. 8-91.

61. Gbadmosi, I.; Adeyi, O.; Oyekanmi, O.; Somade, O. Launea taraxacifolia leaf partitions ameliorates alloxan-induced pathophysiological complications via antioxidant mechanisms in diabetic rats. Metab. Open 2020, 6, 100029. [CrossRef]

62. Adeyi, A.O.; Nneji, L. Ameliorative potentials of medicinal plants on the pathophysiological complications of diabetes mellitus: A review. J. Med. Plants Res. 2015, 9, 262-288. [CrossRef]

63. Al-Doaiss, A.A.; Al-Shehri, M.A. Efecto Protector de la Goma Arábiga/Insulina Contra los Cambios Histológicos en los Testículos de Ratas Diabéticas. Int. J. Morphol. 2020, 38, 340-347. [CrossRef]

64. Navarro-Casado, L.; Juncos-Tobarra, M.; Chafer-Rudilla, M.; De Onzono, L.I.; Blazquez-Cabrera, J.; Miralles-Garcia, J. Effect of experimental diabetes and STZ on male fertility capacity. Study in rats. J. Androl. 2010, 31, 584-592. [CrossRef] [PubMed]

65. Kianifard, D.; Sadrkhanlou, R.A.; Hasanzadeh, S. The ultrastructural changes of the sertoli and leydig cells following streptozotocin induced diabetes. Iran. J. Basic Med. Sci. 2012, 15, 623-635. [PubMed]

66. Du, Z.; Xu, S.; Hu, S.; Yang, H.; Zhou, Z.; Sidhu, K.; Miao, Y.; Liu, Z.; Shen, W.; Reiter, R.J. Melatonin attenuates detrimental effects of diabetes on the niche of mouse spermatogonial stem cells by maintaining Leydig cells. Cell Death Dis. 2018, 9, 1-15. [CrossRef]

67. Adejuwon, S.; Femi-Akinlosotu, O.; Omirinde, J. Cisplatin-induced testicular dysfunction and its amelioration by Launaea taraxacifolia leaf extract. Andrologia 2015, 47, 553-559. [CrossRef] [PubMed]

68. Khan, R.A. Protective effects of Launaea procumbens on rat testis damage by $\mathrm{CCl}_{4}$. Lipids Health Dis. 2012, 11, 103. [CrossRef]

69. Adinortey, M.B.; Agbeko, R.; Boison, D.; Ekloh, W.; Kuatsienu, L.E.; Biney, E.E.; Affum, O.O.; Kwarteng, J.; Nyarko, A.K. Phytomedicines used for diabetes mellitus in Ghana: A systematic search and review of preclinical and clinical evidence. Evid.-Based Complementary Altern. Med. 2019, 2019, 6021209. [CrossRef]

70. AL-Ishaq, R.K.; Abotaleb, M.; Kubatka, P.; Kajo, K.; Büsselberg, D. Flavonoids and their anti-diabetic effects: Cellular mechanisms and effects to improve blood sugar levels. Biomolecules 2019, 9, 430. [CrossRef]

71. Tangvarasittichai, S. Oxidative stress, insulin resistance, dyslipidemia and type 2 diabetes mellitus. World J. Diabetes 2015, 6, 456. [CrossRef]

72. Halban, P.A.; Polonsky, K.S.; Bowden, D.W.; Hawkins, M.A.; Ling, C.; Mather, K.J.; Powers, A.C.; Rhodes, C.J.; Sussel, L.; Weir, G.C. $\beta$-cell failure in type 2 diabetes: Postulated mechanisms and prospects for prevention and treatment. J. Clin. Endocrinol. Metab. 2014, 99, 1983-1992. [CrossRef] [PubMed]

73. Erejuwa, O.O.; Sulaiman, S.A.; Wahab, M.S.A.; Sirajudeen, K.N.S.; Salleh, M.S.M.; Gurtu, S. Antioxidant protective effect of glibenclamide and metformin in combination with honey in pancreas of streptozotocin-induced diabetic rats. Int. J. Mol. Sci. 2010, 11, 2056-2066. [CrossRef]

74. Khan, R.A.; Khan, M.R.; Sahreen, S.; Ahmed, M.; Shah, N.A. Carbon tetrachloride-induced lipid peroxidation and hyperglycemia in rat: A novel study. Toxicol. Ind. Health 2015, 31, 546-553. [CrossRef] [PubMed]

75. Alqasoumi, S.I.; Abdel-Kader, M.S. Terpenoids from Juniperus procera with hepatoprotective activity. Pak. J. Pharm. Sci. 2012, 25, 315-322. [PubMed]

76. El-Newary, S.A.; Ismail, R.F.; Shaffie, N.M.; Hendawy, S.; Omer, E. Hepatoprotective, therapeutic and in vivo anti-oxidant activities of Tagetes lucida leaves alcoholic extract against paracetamol-induced hepatotoxicity rats. Int. J. PharmTech Res. 2016, 9, 327-341.

77. Abd-ElGawad, A.M.; Elshamy, A.; El-Amier, Y.A.; El Gendy, A.; Al-Barati, S.; Dar, B.; Al-Rowaily, S.; Assaeed, A. Chemical composition variations, allelopathic, and antioxidant activities of Symphyotrichum squamatum (Spreng.) Nesom essential oils growing in heterogeneous habitats. Arab. J. Chem. 2020, 13, 237-4245. [CrossRef]

78. Sun, C.; Zhao, C.; Guven, E.C.; Paoli, P.; Simal-Gandara, J.; Ramkumar, K.M.; Wang, S.; Buleu, F.; Pah, A.; Turi, V. Dietary polyphenols as antidiabetic agents: Advances and opportunities. Food Front. 2020, 1, 18-44. [CrossRef]

79. Vinayagam, R.; Jayachandran, M.; Xu, B. Antidiabetic effects of simple phenolic acids: A comprehensive review. Phytother. Res. 2016, 30, 184-199. [CrossRef]

80. Zhang, Z.; Ding, Y.; Dai, X.; Wang, J.; Li, Y. Epigallocatechin-3-gallate protects pro-inflammatory cytokine induced injuries in insulin-producing cells through the mitochondrial pathway. Eur. J. Pharmacol. 2011, 670, 311-316. [CrossRef]

81. Zanatta, L.; Rosso, A.; Folador, P.; Figueiredo, M.S.; Pizzolatti, M.G.; Leite, L.D.; Silva, F.R. Insulinomimetic effect of kaempferol 3-neohesperidoside on the rat soleus muscle. J. Nat. Prod. 2008, 71, 532-535. [CrossRef]

82. Nguyen-Ngo, C.; Salomon, C.; Quak, S.; Lai, A.; Willcox, J.C.; Lappas, M. Nobiletin exerts anti-diabetic and anti-inflammatory effects in an in vitro human model and in vivo murine model of gestational diabetes. Clin. Sci. 2020, 134, 571-592. [CrossRef] [PubMed]

83. Sundaram, R.; Shanthi, P.; Sachdanandam, P. Effect of tangeretin, a polymethoxylated flavone on glucose metabolism in streptozotocin-induced diabetic rats. Phytomedicine 2014, 21, 793-799. [CrossRef] [PubMed]

84. Galadari, S.; Rahman, A.; Pallichankandy, S.; Galadari, A.; Thayyullathil, F. Role of ceramide in diabetes mellitus: Evidence and mechanisms. Lipids Health Dis. 2013, 12, 98. [CrossRef] [PubMed]

85. Boulos, L. Flora of Egypt: Verbenaceae—Compositae; Al Hadara Publishing: Cairo, Egypt, 2002; Volume 3.

86. Tackholm, V. Students Flora of Egypt, 2nd ed.; Cairo University: Cairo, Egypt, 1974.

87. AOAC. Official Methods of Analysis; Association of Official Analytical Chemists: Washington, DC, USA, 2000. 
88. OECD. OECD Guidelines for the Testing of Chemicals No. 423: Acute Oral Toxicity-Acute Toxic Class Method; OECD: Paris, France, 1996.

89. Ravi, K.; Rajasekaran, S.; Subramanian, S. Antihyperglycemic effect of Eugenia jambolana seeds kernel on streptozotocin-induced diabetes in rats. Food Chem. Toxicol. 2005, 43, 1433-1439. [CrossRef] [PubMed]

90. Ghosh, M. Fundamentals of experimental pharmacology. Indian J. Pharmacol. 2007, 39, 216.

91. Garg, R.; Kumar, R.; Nathiya, D.; Goshain, O.; Trivedi, V.; Sharma, A.K.; Murti, K. Comparative acute toxicity studies of selected indigenous herbal plants in Swiss albino mice. IOSR J. Pharm. Biol. Sci. 2016, 11, 20-27.

92. Ekeanyanwu, R.; Udeme, A.; Onuigbo, A.; Etienajirhevwe, O. Anti-diabetic effect of ethanol leaf extract of Cissampelos owariensis (lungwort) on alloxan induced diabetic rats. Afr. J. Biotechnol. 2012, 11, 6758-6762. [CrossRef]

93. Van Pelt, L. Ketamine and xylazine for surgical anesthesia in rats. J. Am. Vet. Med. Assoc. 1977, 171, $842-844$.

94. Allain, C.C.; Poon, L.S.; Chan, C.S.; Richmond, W.; Fu, P.C. Enzymatic determination of total serum cholesterol. Clin. Chem. 1974, 20, 470-475. [CrossRef]

95. Naito, H.K. High-density lipoprotein (HDL) cholesterol. Methods Clin. Chem. 1984, 437, 1207-1213.

96. Fossati, P.; Prencipe, L. Serum triglycerides determined colorimetrically with an enzyme that produces hydrogen peroxide. Clin. Chem. 1982, 28, 2077-2080. [CrossRef]

97. Friedewald, W.T.; Levy, R.I.; Fredrickson, D.S. Estimation of the concentration of low-density lipoprotein cholesterol in plasma, without use of the preparative ultracentrifuge. Clin. Chem. 1972, 18, 499-502. [CrossRef] [PubMed]

98. Kikuchi-Hayakawa, H.; Onodera, N.; Matsubara, S.; Yasuda, E.; Chonan, O.; Takahashi, R.; Ishikawa, F. Effects of soy milk and bifidobacterium fermented soy milk on lipid metabolism in aged ovariectomized rats. Biosci. Biotechnol. Biochem. 1998, 62, 1688-1692. [CrossRef]

99. Henry, R. Clinical Chemistry. Principles and Techniques; Harper \& Row, Publishers: New York, NY, USA, 1964.

100. Doumas, B.T.; Watson, W.A.; Biggs, H.G. Albumin standards and the measurement of serum albumin with bromcresol green. Clin. Chim. Acta 1971, 31, 87-96. [CrossRef]

101. Belfield, A.; Goldberg, D.M. Application of a continuous spectrophotometric assay for 5'nucleotidase activity in normal subjects and patients with liver and bone disease. Clin. Chem. 1969, 15, 931-939. [CrossRef] [PubMed]

102. Rettman, S.; Frankel, L.S. A colorimetric method for the determination of serum glutamic oxalacetic and glutamic pyruvic transaminases. Am. J. Clin. Pathol. 1957, 28, 56-63. [CrossRef] [PubMed]

103. Reinhold, J.G. Standard Methods in Clinical Chemistry; Academic Press: New York, NY, USA, 1953.

104. Tabacco, A.; Meiattini, F.; Moda, E.; Tarli, P. Simplified enzymic/colorimetric serum urea nitrogen determination. Clin. Chem. 1979, 25, 336-337. [CrossRef] [PubMed]

105. Gochman, N.; Schmitz, J.M. Automated determination of uric acid, with use of a uricase-Peroxidase system. Clin. Chem. 1971, 17, 1154-1159. [CrossRef]

106. Faulkner, W.; King, J. Colorimetric detemination of creatinine. In Fundamentals of Clinical Chemistry, 2nd ed.; Tietz, N.W., Ed.; Saunders: Philadelphia, PA, USA, 1976; Volume 994.

107. Ohkawa, H.; Ohishi, N.; Yagi, K. Assay for lipid peroxides in animal tissues by thiobarbituric acid reaction. Anal. Biochem. 1979, 95, 351-358. [CrossRef]

108. Griffith, O.W. Determination of glutathione and glutathione disulfide using glutathione reductase and 2-vinylpyridine. Anal. Biochem. 1980, 106, 207-212. [CrossRef]

109. Goldberg, D.M.; Spooner, R.J. Glutathione reductase. In Methods of Enzymatic Analysis; Bergmeyer, H.U., Bergmeyer, J., GraBI, M., Eds.; Verlag Chemie: Basel, Switzerland, 1983; Volume 3, pp. 258-265.

110. Paglia, D.E.; Valentine, W.N. Studies on the quantitative and qualitative characterization of erythrocyte glutathione peroxidase. $J$. Lab. Clin. Med. 1967, 70, 158-169.

111. Habig, W.H.; Pabst, M.J.; Jakoby, W.B. Glutathione S-transferases the first enzymatic step in mercapturic acid formation. J. Biol. Chem. 1974, 249, 7130-7139. [CrossRef]

112. Beers, R.F.; Sizer, I.W. A spectrophotometric method for measuring the breakdown of hydrogen peroxide by catalase. J. Biol. Chem. 1952, 195, 133-140. [CrossRef]

113. Suvarna, K.S.; Layton, C.; Bancroft, J.D. Bancroft's Theory and Practice of Histological Techniques, 8th ed.; Elsevier: Amsterdam, The Netherlands, 2008.

114. Sakna, S.T.; Mocan, A.; Sultani, H.N.; El-Fiky, N.M.; Wessjohann, L.A.; Farag, M.A. Metabolites profiling of Ziziphus leaf taxa via UHPLC/PDA/ESI-MS in relation to their biological activities. Food Chem. 2019, 293, 233-246. [CrossRef] [PubMed] 